\title{
Final Vowel Loss in Lower Kasai Bantu (DRC) as a Contact-Induced Change
}

\author{
Sara Pacchiarotti \\ Postdoctoral researcher, UGent Centre for Bantu Studies, Department of \\ Languages and Cultures, Ghent University, Ghent, Belgium \\ sara.pacchiarotti@ugent.be
}

\begin{abstract}
Koen Bostoen
Professor of African Linguistics and Swahili, UGent Centre for Bantu Studies, Department of Languages and Cultures, Ghent University, Ghent, Belgium koen.bostoen@ugent.be
\end{abstract}

\begin{abstract}
In this article, we present a qualitative and quantitative comparative account of Final Vowel Loss (FVL) in the Bantu languages of the Lower Kasai region of the Democratic Republic of the Congo. We argue that this diachronic sound shift rose relatively late in Bantu language history as a contact-induced change and affected adjacent West-Coastal and Central-Western Bantu languages belonging to different phylogenetic clusters. We account for its emergence and spread by resorting to two successive processes of language contact: (1) substrate influence from extinct hunter-gatherer languages in the center of innovation consisting of Bantu B8o languages, and (2) dialectal diffusion towards certain peripheral Bantu $\mathrm{B} 7 \mathrm{O}, \mathrm{C} 8 \mathrm{O}, \mathrm{H} 4 \mathrm{O}$ and Lio languages.
\end{abstract}

\section{Keywords}

final vowel loss - West-Coastal Bantu - Central-Western Bantu - dialectal diffusion - substrate influence 


\section{Introduction}

Final Vowel Loss (FVL) has been observed in different parts of the northwestern Bantu domain (cf. Guthrie, 1953; 1967; Hyman, 2019: 130), but its origins and development have not been studied in any systematic way. This article is a first attempt to systematically analyze FVL as a diachronic sound change in a Bantu-speaking region where it is known to be prolific, i.e., the Lower Kasai region of the Democratic Republic of the Congo (DRC) (Daeleman, 1977; Rottland, 1977). An in-depth study of this relatively uncommon Bantu feature within this specific territory is not only desirable from a purely linguistic point of view, but also from a broader cultural historical perspective. In fact, this peculiar phonological feature has drawn the attention of historians such as Vansina (1973-1974: 336-337; 1974) and Hoover (1978: 58-62) who take it as indicative of regional exchange networks and population dynamics in pre-colonial times. However, in order to establish prehistoric (language) contact based on its linguistic effects (cf. Ross, 2003; 2013; Thomason, 2008), it is crucial to have a profound historical linguistic understanding of the potential contact phenomenon in question. The main objectives of this article are first to present the results of a thorough diachronic analysis of FVL in the Lower Kasai region and then to consider the possible socio-cultural historical processes that may have led to its emergence and spread. In Section 2, we discuss the defining features of FVL in the Lower Kasai region. In Section 3, we delimit more specifically the geographic distribution of the phenomenon and consider its time depth with regard to the phylogeny of the Bantu language family. In Section 4, we assess the relative chronology of FVL with regard to other common sound changes in the Lower Kasai region. In Section 5 , we present the results of a quantitative study of FVL in order to evaluate its historical impact on the lexicon of the languages concerned. In Section 6 , we elaborate on the different historical processes that may have triggered its emergence and diffusion as a contact-induced change. Conclusions are in Section 7 .

Before starting the discussion, we present in (1) the key languages considered here along with their alphanumeric code following the referential classification of the Bantu languages (Guthrie, 1971; Maho, 20o9; Pacchiarotti et al., 2019) as well as the sources from which we extracted data for this comparative research. 
(1) The main languages considered in this study

\begin{tabular}{|c|c|}
\hline Ngungwel B72a & $(\text { Ruth Raharamanintsoa p.c. })^{1}$ \\
\hline Boma Yumu B8oz ${ }^{2}$ & (Burssens, 1999; Koni Muluwa and Bostoen, 2015) \\
\hline Yans $B 85^{3}$ & $\begin{array}{l}\text { (Swartenbroeckx, 1948; Mufwene, 1973; Rottland, 1977; } \\
\text { Nguma-Nanzioke, 1983; Koni Muluwa and Bostoen, } \\
\text { 2015) }\end{array}$ \\
\hline Nsong B85d & $\begin{array}{l}\text { (Dibata Mimpya, 1979; Koni Muluwa, 2015; Koni } \\
\text { Muluwa and Bostoen, 2015) }\end{array}$ \\
\hline Mpur B85e & (Mbwetete, 1984; Koni Muluwa and Bostoen, 2015) \\
\hline Nsambaan $\mathrm{B}_{5} \mathrm{~F}$ & (Koni Muluwa, 2014; Koni Muluwa and Bostoen, 2015) \\
\hline Ngwi B861 & (own fieldwork) \\
\hline Lwel B862 & (Khang Levy, 1979; Koni Muluwa and Bostoen, 2015) \\
\hline Mpiin B863 & (Koni Muluwa and Bostoen, 2015) \\
\hline Ngong B864 & (Koni Muluwa and Bostoen, 2015) \\
\hline Nzadi B865 & (Crane et al., 2011; Koni Muluwa and Bostoen, 2015) \\
\hline Ding B86 & $\begin{array}{l}\text { (Kitoko Mufanga, 1978; Ebalantshim Masuwan, 1980; } \\
\text { Koni Muluwa and Bostoen, 2015) }\end{array}$ \\
\hline Mbuun B87 & (Mundeke, 1979; Koni Muluwa and Bostoen, 2015) \\
\hline Bushong C83 & (Vansina, 1959; Daeleman, 1977) \\
\hline Lele C84 & (Ngwamashi Kabandji-Bola Kamu, 1979; 1981) \\
\hline Wonk C85 & (Tete Wer Sey, 1975; Koni Muluwa and Bostoen, 2015) \\
\hline Hungan $\mathrm{H}_{42}$ & (Koni Muluwa and Bostoen, 2015) \\
\hline Samba Li2a & (Van Acker and Bostoen, 2020) \\
\hline
\end{tabular}

We define FVL in the Lower Kasai region as the historical loss of the word-final vowel segment in the reflexes of polysyllabic nominal and verbal stems found in the Bantu Lexical Reconstructions (BLR) 3 database (Bastin et al., 2002). These have the shapes ${ }^{*} \mathrm{CVCV}$, where $\mathrm{C}$ stands for any consonant including nasals, and ${ }^{*} \mathrm{CVNCV}$, where NC stands for a nasal consonant cluster (e.g., ${ }^{*} \mathrm{mb}$,

1 We are extremely grateful to Ruth Raharimanantsoa from siL Congo for generously sharing with us an unpublished comparative 6oo-wordlist of four Teke varieties (Ngungwel B72a, Tyee B73d, Eboo-Nzikou B74, and Kukwa B77a).

2 B8oz indicates that Boma Yumu is a Bantu variety not inventoried in Guthrie (1971) or Maho (2009). We tentatively place it in Guthrie's B8o referential group (see Pacchiarotti et al., 2019: 165).

3 For languages like Yans B85, Ding B86 and Mbuun B87, we collapsed several distinct dialectal varieties under a single label. In the Appendix, we inconsistently distinguish only West Yans B85a (Swartenbroeckx, 1948) from East Yans B85b (Mufwene, 1973; Rottland, 1977; NgumaNanzioke, 1983; Koni Muluwa and Bostoen, 2015). 
* $\left.n d,{ }^{*} \eta g\right)$. Throughout this paper $\mathrm{C} 1, \mathrm{~V} 1, \mathrm{C} 2, \mathrm{~V} 2$ etc. mean e.g., in C(onsonant) 1 position within a $\mathrm{C}_{1} \mathrm{~V}_{1} \mathrm{C}_{2} \mathrm{~V}_{2}$ template. This diachronic sound change created closed syllables in final position. As such, FVL in this article includes neither vowel hiatus resolution strategies, e.g., final vowel deletion or epenthetic consonant insertion in vowel sequences across word boundaries that still end in a vowel after vowel deletion (cf. Meinhof and van Warmelo, 1932: 4), nor vowels which get deleted between consonants during fast speech, as reported by Harford and Malambe (2015) for high vowels in Swati S43, for example. Our definition of FVL does not cover phonologically conditioned instances of vowel deletion either, as in Sotho $S_{3}$ languages and other groups allowing word-final nasals as a result of vowel deletion in /ni/ and /mu/ sequences (cf. Odden, 2015).

In (2), we illustrate FVL in the Lower Kasai region with data from the eastern variety of Ngwi (B861) spoken on the left bank of the Kasai River in the DRC (see Fig. 1). The protoforms in (2) are obtained from the BLR3 database (Bastin et al., 2002). The symbol ">" introduces the Ngwi synchronic reflex of a protoform. We indicate meaning of a reflex only if it differs from that of the protoform.

(2) Ngwi B861

\begin{tabular}{|c|c|c|}
\hline \multirow[t]{19}{*}{${ }^{*} \mathrm{CVCV}$} & BLR 2410 *pàpá ‘wing’ & $>i-p a \check{\beta}$ \\
\hline & BLR 638 *còbó 'intestines' & $>\grave{o}-s \check{\partial} \beta$ \\
\hline & BLR 394 *càbuk-a 'cross (a river)' & $>s \check{a} \beta$ \\
\hline & BLR 3252 *játò 'canoe' & $>w-\hat{a} r$ \\
\hline & BLR 5395 *gútù ‘calabash’ & $>\grave{e}-p f \hat{j} j$ \\
\hline & BLR 1674 *kádí 'woman, wife' & $>\grave{o}-\eta k \varepsilon ́ a ̀ r$ 'woman' \\
\hline & BLR 6 o ${ }^{*}$ cíd-a 'finish' & $>\int i r$ \\
\hline & BLR 897 *dèdù 'beard' & $>\grave{e}-l \hat{\varepsilon} y$ \\
\hline & BLR 1798 *kímà ‘monkey’ & $>\emptyset-\eta k \hat{\partial} m$ \\
\hline & BLR 8211 *pámi 'man, male' & > ò-mpéàm \\
\hline & BLR 2895 *tímà 'heart' & $>\grave{o}-t \hat{m} m$ \\
\hline & BLR 2042 *kóni 'firewood' & $>\emptyset-\eta k \hat{u} \eta$ \\
\hline & BLR 2976 *tóná 'spot, speckle' & $>i-t \hat{n} n$ \\
\hline & BLR 6108 *cìkà 'girl, woman' & $\begin{array}{l}>\grave{o} \text {-sât 'girl, unmarried } \\
\text { woman' }\end{array}$ \\
\hline & BLR 5455 *túká 'banana' & > ’̀-tsûs 'banana bunch' \\
\hline & BLR $95^{82}$ *dák-a ‘walk’ & $>\operatorname{lă} B$ \\
\hline & BLR 1248 *dúg-a 'paddle (v.)' & $>l \hat{u} B$ \\
\hline & BLR 812 *dàgá 'promise' & $\begin{array}{l}>\grave{e} \text {-lăb 'engagement, } \\
\text { promise' }\end{array}$ \\
\hline & BLR 1621 *jògớ 'groundnut' & $>\grave{e}-y \breve{u} b$ \\
\hline
\end{tabular}




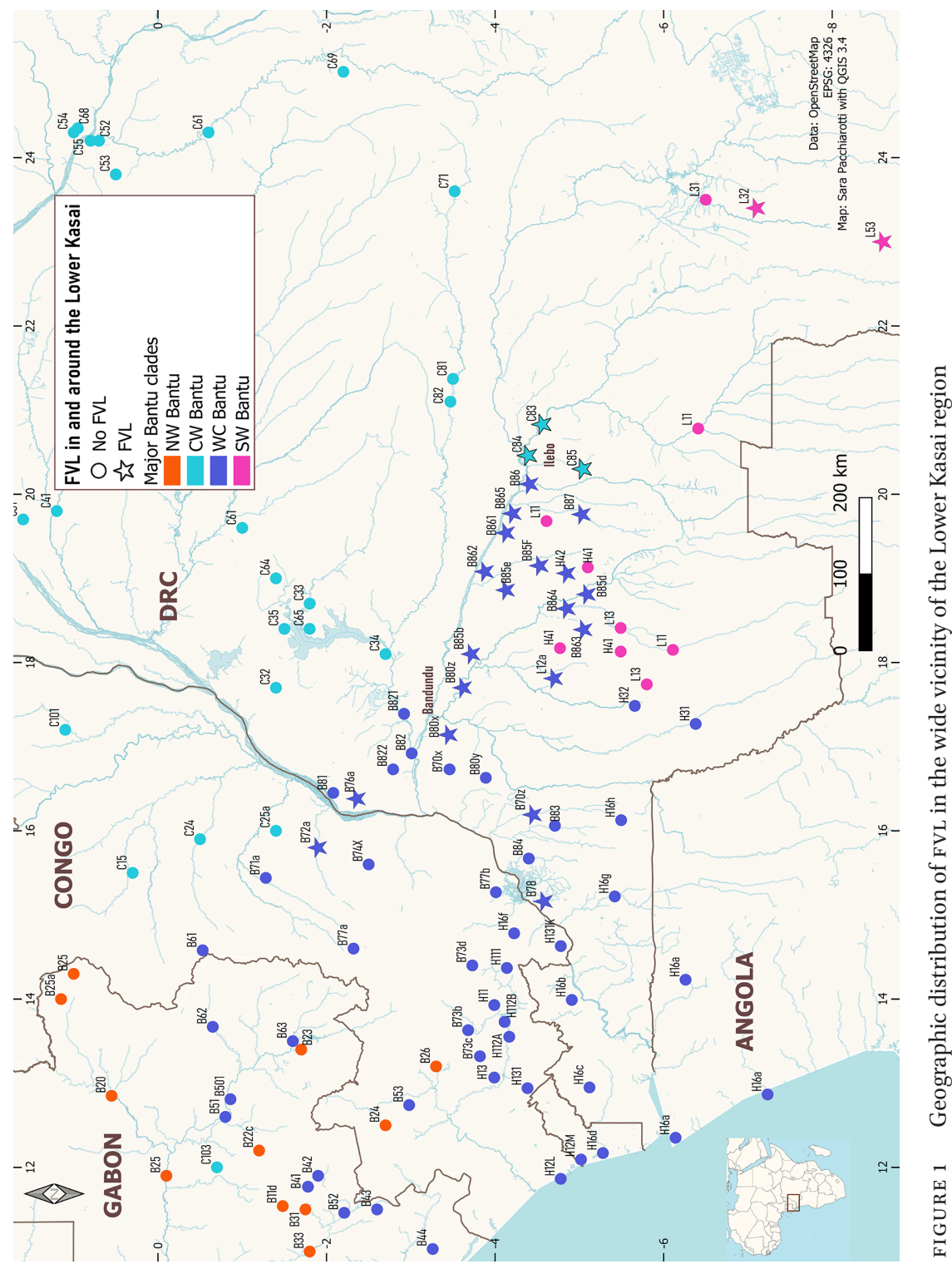




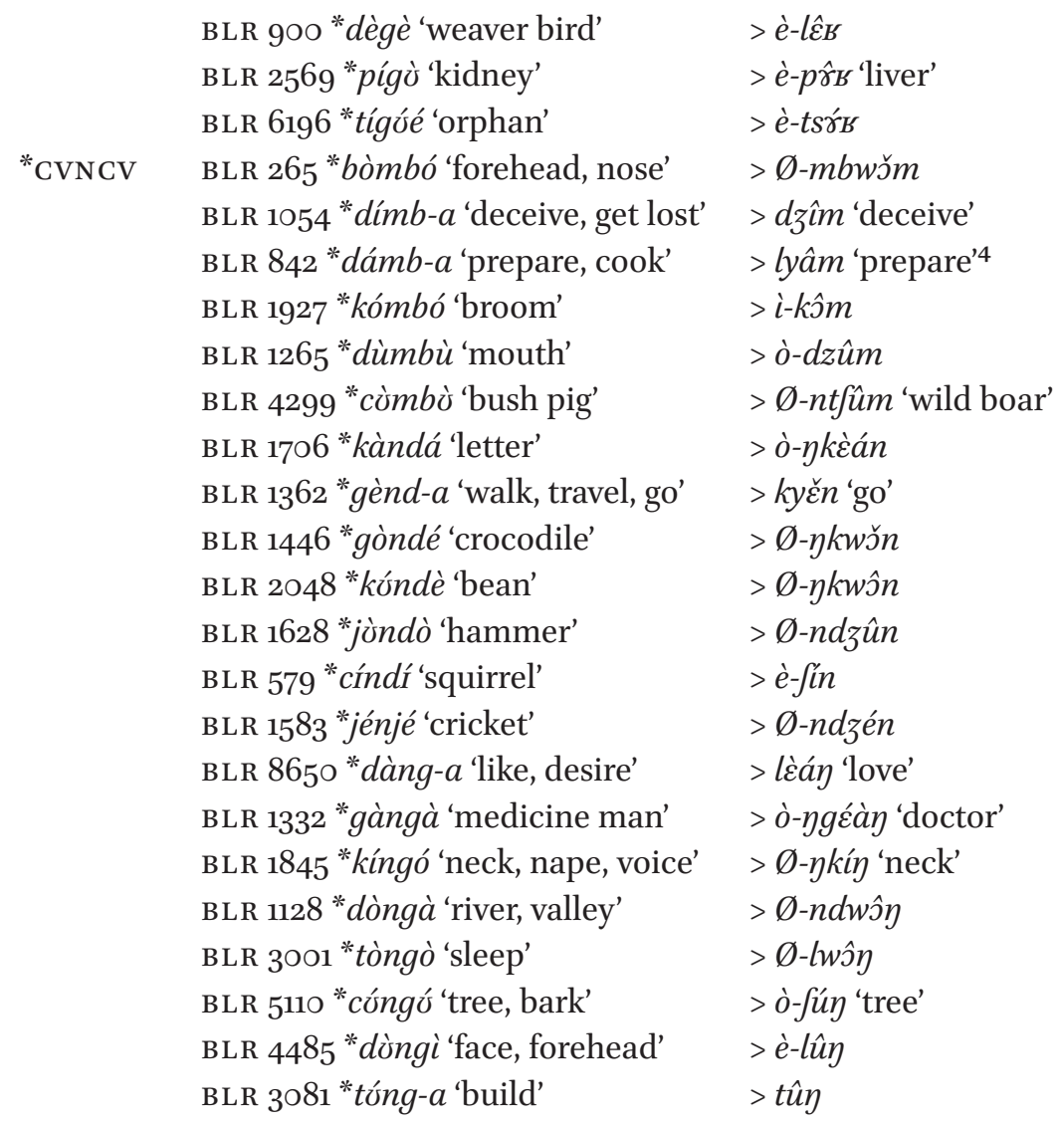

The data in (2) illustrate three features of FVL shared by almost all Lower Kasai languages that underwent the change (cf. Figure 1).

First, the loss of a word final vocalic segment is not phonologically and/or prosodically determined or constrained. As can be seen in (2), FVL occurred in all phonotactically suitable environments (i.e., historical CVCV and CVNCV shapes) regardless of the manner and place of articulation of $\mathrm{C}_{2}$ and of the quality of the reconstructed final vowel. In this sense, FVL in the Lower Kasai is different from FVL in some Bantu languages of Guthrie's (1971) zones A and C, such as Kwakum A91 where stems with more than one syllable lose their final $|i|,|u|,|\varepsilon|$ or $\mid \jmath /$ in non-prepausal position (Njantcho Kouagang, 2018: 33), and Nkundo C61 where final $/ i /$ and $/ u /$ get deleted if preceded by $/ m /$, e.g.,

4 The diphthong $\mid y a /$ in the synchronic form lyâm suggests that the protoform giving rise to this reflex had a verbal suffix with a front vowel, perhaps Рв applicative *-Id, i.e., *dámb-Id 'to prepare, to cook for someone'. 
bìnkìmú > bìnkj̀m 'tree (species)' (Grégoire, 2003: 353$).{ }^{5}$ It is also different in nature from synchronic phonological processes of final vowel reduction leading to word-final closed syllables (cf. Mous, 2003: 286, for Nen A44; Lovestrand, 2011: 21, for Nyokon A45) in that FVL in the Lower Kasai is not a synchronic process but a diachronic sound change.

Second, before disappearing, certain historical final vowels had assimilation effects on the first vowel of the root/stem. For instance, in Ngwi B861, ProtoBantu $(\mathrm{PB}){ }^{*} \mathrm{v}$ in $\mathrm{V}_{2}$ caused the assimilation of a front $\mathrm{V}_{1}$ to the feature [+back],

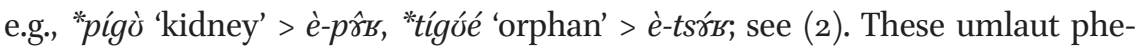
nomena are extremely common in other Lower Kasai languages displaying FVL, such as Yans B85, Ding B86, Mpur B85e, Nsong B85d, Mbuun B87, Mpiin B863 and Ngong B864 (see Bostoen and Koni Muluwa, 2014, for a detailed account). In Ngwi, $\mathrm{PB}^{*} i$ in $\mathrm{V}_{2}$ caused umlaut involving diphthongization in $\mathrm{V}_{1}$ position (see Koni Muluwa and Bostoen 2012 for diphthongization in other Lower Kasai languages). This diphthong was apparently later reanalyzed as a sequence of two

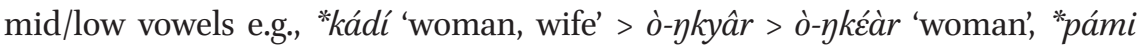
'man, male' > ò-mpéàm. A historical *i also palatalized a preceding alveolar nasal, e.g., "kóni 'firewood' > kûn.

Third, as discussed in Rottland (1977) for Yans B85 and Mundeke (2011) for Mbuun B87, if the tone pattern of the reconstruction was either $\mathrm{HL}$ or $\mathrm{LH}, \mathrm{V} 2$ was lost but its tone was preserved and created a contour tone by interacting with the tone on $\mathrm{V} 1$, cf. BLR $812{ }^{*}$ dàgá > dàg' > Ngwi lăb. This process gave rise to (phonologically contrastive) contour tones in many of the Lower Kasai varieties that underwent FVL, such as Mpur B85e (Mbwetete, 1984), East Ding B86 (Mula, 1977), Ngwi B861 (own fieldwork), Lwel B862 (Khang Levy, 1979), Nzadi B865 (Crane et al., 2011), Bushong C83 (Daeleman, 1977), and Wonk C85 (Tete Wer Sey, 1975). ${ }^{6}$ It is likely that this phenomenon is found in several other languages that lost a final vowel, but a lack of basic phonological descriptions prevents us from drawing firm conclusions. As far as tonal outcome goes, the Lower Kasai languages thus have a tendency to maintain the tone of the lost

5 Grégoire (2003: 353) notes that Meeussen (1952) describes the same phenomenon in Ombo $\mathrm{C}_{7} 6$.

6 The Ngwi data in (2) is particularly telling in this regard. Most historical *LL and *HH noun roots became HL (or Falling when realized on a single, phonetically lengthened vowel) in

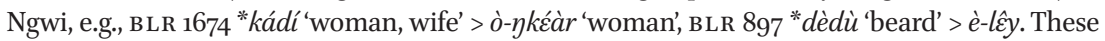
tone shifts are still visible on $\mathrm{V}_{1}$ where they created a contour tone just like it happened with historical ${ }^{*} \mathrm{HL}$ and ${ }^{*} \mathrm{LH}$ roots whose tone patterns were preserved as such, e.g., BLR 2895 *tímà 'heart' > ò-tâm, BLR 265 *bòmbó 'forehead, nose' > Ø-mbwǒm. These tonal innovations in Ngwi must have happened before final vowel loss, which is in line with our hypothesis (see Section 4) that final vowel loss must be a relatively late diachronic change. 
final vowel or syllable as a feature of the root, often forming a tonal contour when it joined with the preceding root tone. ${ }^{7}$ In this respect, FVL in the Lower Kasai region resembles FVL in Grassfields Bantu (Watters, 2003: 236), as well as in some zone A languages, such as the Manenguba A15 languages (Hedinger, 2006), Mbene A43a (Guthrie, 1967: 56 and ff.), Basaá A43 (Heath, 2003: 25726o), Eton A71 (van de Velde, 2008: 96), Bulu A74, Fang A75 (Guthrie, 1967: 56 and ff.), and the A8o languages (Heath, 2003: 337; Cheucle, 2008; 2014).

While FVL targeted all * $\mathrm{CVCV}$ and ${ }^{*} \mathrm{CVNCV}$ polysyllabic stems in the Lower Kasai languages concerned, monosyllabic stems reconstructed as ${ }^{*} \mathrm{CV},{ }^{*} \mathrm{CVV}$ and *NCV underwent this change very irregularly as shown in (3)-(8). These data show that certain reconstructed monosyllabic stems almost never lose a final vowel, see (3) and (4), while others do lose it across (almost) all languages, see (5) and (6). There are also intermediate cases where the final vowel is lost in roughly half of the languages which have reflexes for that root, see (7) and (8). Note that in some cases, e.g., (5), an erstwhile noun class prefix was reanalyzed in individual languages as being part of the reconstructed ${ }^{*} \mathrm{CV}$ stem, making it into a CVCV shape.

(3) Reflexes of BLR 2881 *tí 'tree, stick, medicine'

\begin{tabular}{|c|c|c|c|c|c|}
\hline B85b & ò-té/mì-té & B862 & yà-tá/mà-tá & $\mathrm{C} 84$ & n-té/mi-té \\
\hline B85d & $m \dot{s}^{-t i ̀ ~}$ & B864 & mó-tì/mí-tì & $\mathrm{C} 85$ & n-té/mi-té \\
\hline B85e & $\dot{u}-t i / i-t i$ & B865 & $\grave{o}-t e ́$ & $\mathrm{H}_{42}$ & $m \grave{u}-t i ́$ \\
\hline $\mathrm{B} 85^{\mathrm{F}}$ & $m a ́-t i / m i-t i$ & B86 & mù-té/mì-té & L12a & $m u ́-d / m i ́-d$ \\
\hline B861 & è-tá & B87 & j̀-té/غे-té & & \\
\hline
\end{tabular}

(4) Reflexes of BLR 3023 *túe 'head'

\begin{tabular}{|c|c|c|c|c|c|}
\hline B8oz & $m \grave{-}-t \int w \varepsilon ́$ & B862 & ngà-tsá & $\mathrm{C} 83$ & n-tswéy \\
\hline B85b & $m \overline{-}-t s w \bar{\varepsilon}$ & B863 & $m \dot{-}-t s w I ́$ & $\mathrm{C} 85$ & $n$-tswé \\
\hline B85d & mó-tswì & B864 & 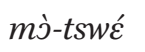 & $\mathrm{H}_{42}$ & $m \grave{u}-t w \varepsilon ́$ \\
\hline B85e & $\grave{u}-n t s w \varepsilon ́$ & B865 & j̀-tsó & L12a & $m \grave{u}-d / m \grave{\imath}-d$ \\
\hline $\mathrm{B} 8{ }_{5} \mathrm{~F}$ & $m \grave{a}-t w e ́$ & B86 & $m \grave{u}-t s w \mathcal{E}$ & & \\
\hline B861 & $\grave{o}-t \dot{\varepsilon}$ & B87 & $\grave{o}-t s w \varepsilon ́$ & & \\
\hline
\end{tabular}

7 A question that awaits further research is whether contour tones in the Lower Kasai area are hosted on one or two moras or, in other words, whether the loss of a final segment caused compensatory lengthening of the first vowel. 
(5) Reflexes of BLR 781 *dá 'village' (CL14 bu)

$\begin{array}{lllllll}\mathrm{B} 85 \mathrm{~b} & \text { bầl } & \mathrm{B} 85 \mathrm{~F} & \emptyset \text {-bwáàl } & \mathrm{B} 864 & \text { Ø-búl } & \text { C84 ból } \\ \mathrm{B} 85 \mathrm{~d} & \emptyset \text {-bwáàl } & \mathrm{B} 862 & \text { i-băl } & \mathrm{B} 87 & \emptyset \text {-ból/Ø-bǒl } \\ \mathrm{B} 85 \mathrm{e} & \text { búl } & \mathrm{B} 863 & \emptyset \text {-bwáàl } & \mathrm{C} 83 & \text { bò-l/mà-l }\end{array}$

(6) Reflexes of BLR 3005 *ntì 'person'

$\begin{array}{llllll}\mathrm{B} 8 \mathrm{Oz} & \text { mwù-r/ba-r } & \mathrm{B} 861 & \emptyset \text {-wûr/a-véàr } & \mathrm{C} 83 & \text { mòò-t/bàà-t } \\ \mathrm{B} 85 \mathrm{a} & \text { mùù-r/bàà-r } & \mathrm{B} 862 & \text { yù-r/bàà-r } & \mathrm{C} 84 & \text { mò-tù/bà-tù } \\ \mathrm{B} 85 \mathrm{~d} & \text { mù-nd/bà-nd } & \mathrm{B} 863 & \text { mú-nd/bá-nd } & \mathrm{C} 85 & \text { mòò-t/bàà-t } \\ \mathrm{B} 85 \mathrm{e} & \text { mbù-r/bàà-r } & \mathrm{B} 864 & \text { mùú-t/bá-t } & \mathrm{H} 42 & \text { mù-t/bă-t } \\ \mathrm{B} 85 \mathrm{~F} & \text { mbùù-r/bàà-r } & \mathrm{B} 865 & \text { mùù-r/bàà-r } & \mathrm{L} 12 \mathrm{a} & \text { mú-d/bá-d } \\ \mathrm{B} 86 & \text { mùù-r/bàà-r } & \mathrm{B} 87 & \text { mùù-r/bàà-r } & & \end{array}$

(7) Reflexes of BLR 584 *cí 'inhabitant'

\begin{tabular}{|c|c|c|c|}
\hline$b u ́-s / b i-s$ & B863 bi-s & $\mathrm{C} 85$ & $n$-sí \\
\hline ú-nsí/åa-nsí & B864 mú-J/bí-f & $\mathrm{H}_{42}$ & $m u-\int i / b i-f i$ \\
\hline ya-sá & B865 nsí & L12a & mú-sí \\
\hline
\end{tabular}

(8) Reflexes of BLR 1521 * gúá 'salt'

\begin{tabular}{|c|c|c|c|c|c|}
\hline B8oz & $m \grave{u}-n g b a^{8}$ & B861 & ò-kúá & $\mathrm{H}_{42}$ & $m u ́-\eta$ \\
\hline B85b & $m \grave{u}-n g w a ́$ & B865 & $\grave{o}-k p a ́$ & L12a & $m u ́-n g$ \\
\hline B86 & $m \grave{u}-\eta$ & B87 & $m u ́-\eta$ & & \\
\hline
\end{tabular}

Verb roots/stems also deserve a special mention. As shown with Ngwi data in (2), verb stems (minimally in their infinitive form) consistently lost their final vowels in the languages under study. However, there is variation in the treatment of historical derivational verbal suffixes (see also Guthrie, 1967: 6o). Depending on the language and on the verb root, some of these suffixes underwent phonological reduction, erosion, metathesis, and/or were the target of phonological mergers (cf. Guthrie, 196o; Rottland, 1970; Bostoen and Mundeke, 2011), as can be seen in $(9)-(11){ }^{9}$

8 As is the case in several Central-Western Bantu languages of Guthrie's C30-40 groups spoken between the Ubangi and Congo Rivers (Bostoen and Donzo, 2013: 450-451), the sequence $k w$ followed by a vowel is occasionally turned into a labial-velar stop in some languages belonging to Guthrie's B8o group.

9 Obviously not all verbal derivational suffixes undergo the same sound changes in one and the same variety. For instance, in Nzadi B865 *cón-rk 'write +stative' > ò-sònkà 'write', *táng-ic 'read +causative' > ò-táysà 'to teach', but *càk-ød 'weed + reversive' > ò-sàkùl 'to clear ground'. 
(9) Reflexes of BLR 662 *cónik 'draw a line, write'

$\begin{array}{llllll}\mathrm{B} 8 \mathrm{oz} & \grave{o} \text {-sónikà } & \mathrm{B} 85 \mathrm{e} & \grave{o} \text {-són } & \mathrm{L} 12 \mathrm{a} & \text { sónìg } \\ \mathrm{B} 85 \mathrm{~b} & \grave{o} \text {-s̀̀n } & \mathrm{B} 865 & \dot{o} \text {-sònkà } & & \\ \mathrm{B} 85 \mathrm{~d} & \text { sònik } & \mathrm{B} 87 & \grave{o} \text {-sj̀n } & & \end{array}$

(10) Reflexes of BLR 8257 *jánam 'dry, be spread out'

$\begin{array}{llll}\mathrm{B} 85 \mathrm{~b} & \text { kù-yáán } & \mathrm{B} 86 & \text { kù-yáy } \\ \mathrm{B} 85 \mathrm{~d} & \text { kù-yáná } & \mathrm{B} 865 & \text { o-yây } \\ \mathrm{B} 85 \mathrm{~F} & \text { kà-wáná } & \mathrm{B} 87 & \text { kà-wáná }\end{array}$

(11) Reflexes of BLR 394 *àbok 'cross river'

\begin{tabular}{|c|c|c|c|c|c|}
\hline B8oz & ó-sàkàb & B861 & să $\beta$ & $\mathrm{C} 85$ & kù-sàp \\
\hline B85b & $\begin{array}{l}o \text { o-sàkàb } \\
\text { o-sàbòk }\end{array}$ & B862 & $\grave{o}$-sàb & $\mathrm{H}_{42}$ & kù-sábák \\
\hline $\mathrm{B} 85 \mathrm{~F}$ & kà-sàbà & B864 & kj̀-sábál & Li2a & sábúg \\
\hline
\end{tabular}

\section{Distribution of FVL inside and outside the Lower Kasai Region}

Figure 1 shows the geographical distribution of the Lower Kasai languages displaying different degrees of FVL as defined in Section 2. The Bantu subgroups and their colors in Figure 1 correspond to the phylogenetic clades identified in Grollemund et al. (2015): North-Western Bantu (NWB), Central-Western Bantu (сшв), South-Western Bantu (swв) and West-Western Bantu, to which we refer here as 'West-Coastal Bantu' (WCB) (in line with Vansina, 1995; Bastin et al., 1999; Bostoen et al., 2015; de Schryver et al., 2015; Bostoen and de Schryver, 2018a, b; Pacchiarotti et al., 2019). In order to show that the distribution of FVL in the Lower Kasai region is geographically constrained and absent in surrounding languages, we also plot on Fig. 1 Bantu languages spoken around the Lower Kasai region which do not lose final vowels.

As can be observed in Fig. 1, WCB varieties with FVL in the Lower Kasai region of the DRC are confined to the left bank of the Kasai River and the lands west and south of it, roughly between the cities of Bandundu and Ilebo (between $17.38,-3.31$ and 20.58, -4.33), mostly in today's Kwilu Province. Detached from that bunch of contiguous FVL languages, but still in the same macro-region, Ngungwel B72a is the only wсв language in the Republic of the Congo also displaying this sound change. Certain Teke varieties, such as Bwala B7oy (Bollaert, 2019), Mosieno B76a (Bastin et al., 1999), Wuumu B78 (Bastin et al., 1999) and 
Boma Nkuu B8ox (Nsuka Nkutsi, 199o), which are geographically midway between Ngungwel B72a and the Lower Kasai FVL cluster, sporadically manifest FVL, as far as the very scanty available sources (mostly wordlists) allow us to observe. Due to the paucity of the data, we do not include them in the case study in Section $5^{10}$

The geographic concentration of FVL in the Lower Kasai region is all the more apparent if one considers that these languages are surrounded in all cardinal directions by languages not having undergone this change. To the west, FVL is absent from the rest of east. To the north, neither the NWB nor the сшв languages bordering ШСв (to which most Lower Kasai FVL languages belong) attest the phenomenon. Final vowel devoicing has been reported in Leke C14, Zamba C322 (Grégoire, 2003: 353) and the B3o languages (van der Veen, 2003: 378), but without loss. Phonologically (un)conditioned FVL has been reported in several NWB languages, all considerably further north: A15 (Hedinger, 2006); A40: Basaá A43 (Janssens, 1982), Mbene A43a (Guthrie, 1967), Nen A44 (Janssens, 1993; Mous, 2003), Nyokon A45 (Lovestrand, 2011); A70: Eton A71 (van de Velde, 2008), Bulu A74 (Guthrie, 1967), Fang A75 (Guthrie, 1967; Medjo Mvé, 1997); A8o (Heath, 2003: 337; Cheucle, 2008; 2014); and Kwakum A91 (Njantcho Kouagang, 2018). Given the huge geographical distance separating these zone A languages from the Lower Kasai region, the most plausible assumption is to posit FVL as an independent development. To the south, phonologically unconditioned FVL is absent from the swB languages immediately adjacent to the Lower Kasai region. It is only common in the swb languages Kanyok L32 (Mukash Kalel, 1982) and Ruund L53 (Vincke, 1966; Hoover, 1978: 58-62; Nash, 1992). According to Hoover (1978: 59-61), there is some degree of FVL also in Kete L21 and in some varieties of Luba L31a there is a "marked deemphasis on final vowels". Since these swв languages are spoken several hundred kilometers to the southeast of the Lower Kasai languages, we assume that FVL arose there too as an independent development, parallel to languages which undergo the same phenomenon in the northwest.

10 We also note that Guthrie (1968: 103) reports the existence of a so-called "latent vowel" in the шсв language Nzebi $5_{52}$ spoken in Gabon. He indicates this by means of parentheses around the vowel in question, e.g., $\operatorname{m\varepsilon \varepsilon d}(i)$ 'oil'. Guthrie argues that in Nzebi B52 and other languages of the area, there are at least two speech styles, which he calls "normal" and "deliberate". Sentences pronounced in "normal" speech contain words without final vowels in his transcription, while sentences pronounced in "deliberate" speech contain words with final vowels. We do not know the robustness or extent of this phenomenon, but it is certainly not a case of diachronic FVL as defined in Section 2. 


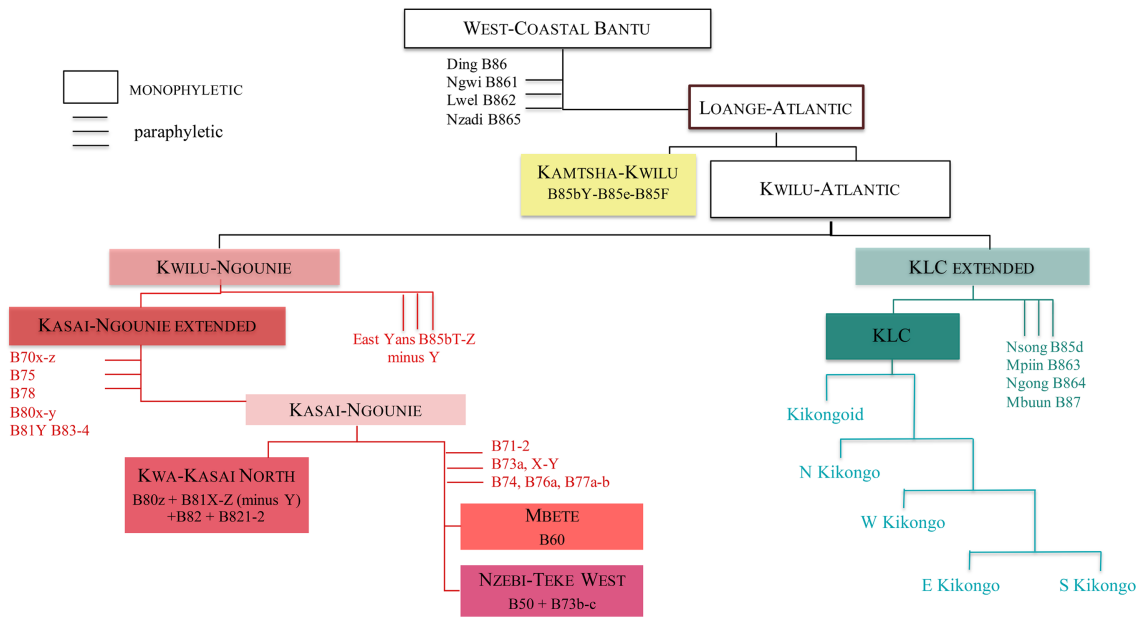

FIGURE 2 Internal lexicon-based phylogenetic classification of шСв (de Schryver et al., 2015; Pacchiarotti et al., 2019)

With regard to the phylogeny of the Bantu family (Grollemund et al., 2015), the Lower Kasai FVL languages belong to two distinct major clades, i.e., WC B and сшв. While the vast majority is part of Bushong C83, Lele C84 and Wonk C85. The rest of Guthrie's C8o group, i.e., Dengese C81 (Goemaere, 1984) and Hendo C82 (Motingea Mangulu, 1990), as well as other сшв languages, i.e., Guthrie's entire zone $\mathrm{C}$ and some zone D languages (cf. Grégoire, 2003), do not undergo FVL at all (see Section 2 for details). Within WCB, taking into account the phylogenies of de Schryver et al. (2015; for the Kikongo Language Cluster, henceforth KLC) and Pacchiarotti et al. (2019; for the entire ШС в branch) summarized in Fig. 2, FVL is distributed unevenly across different subclades.

There is only one monophyletic group in which FVL occurs in all languages, i.e., Kamtsha-Kwilu, but it only consists of three varieties, i.e., Mpur B85e, Nsambaan $\mathrm{B} 85 \mathrm{~F}$ and one doculect of East Yans B85bY. Within the monophyletic Kwilu-Atlantic superclade, parallel to Kamtsha-Kwilu, FVL is attested in its two subclades, i.e., Kwilu-Ngounie and KLC Extended, but in a very patchy way. Only three Kwilu-Ngounie languages underwent it as a regular diachronic sound shift and they all belong to different subgroups within the subclade: Yans B85 (Kwilu-Ngounie paraphyletic), ${ }^{11}$ Boma Yumu B8oz (Kwilu-Ngounie

11 In phylogeny, members of a clade belonging to a paraphyletic grade have no more recent common ancestor that the most recent common ancestor of the entire clade. This contrasts with members of a monophyletic group or subclade, which share a common ancestor that is more recent than the one at the origin of the entire clade. 
$>$ Kasai-Ngounie > Kwa-Kasai North) and Ngungwel B72a (Kwilu-Ngounie > Kasai-Ngounie $\sim$ paraphyletic). Within the KLC Extended, FVL occurs in all paraphyletic languages at the top of the subclade, i.e., Nsong B85d, Mpiin B863, Ngong B864, Mbuun B87, and in only two languages of the KLC subgroup, i.e., Samba L12a and Hungan $\mathrm{H}_{42}$ (KLC Extended $>$ KLC > Kikongoid). Finally, FVL is also attested in the first paraphyletic offshoots of the ancestral WCB node, i.e., Ding B86, Ngwi B861, Lwel B862, and Nzadi B865.

The uneven distribution of FVL across WCB subgroups suggests first that this is a relatively late innovation and second that it is rather areal than inherited. Apart from the very small Kamtsha-Kwilu subclade, it cannot be reconstructed back to the most recent common ancestor of any of the WCB subclades. Although varieties with FVL are scattered throughout the phylogenetic tree, in each of the branches where they are found, there are varieties which never lose their final vowels. Because it is unconceivable that languages from different ШCB subclades would have independently reinserted the same ancestral final vowels, the reconstruction of FVL at some node of шСв is impossible, except maybe in Proto-Kamtsha-Kwilu. The fact that the languages sharing FVL not only belong to different WCB subgroups, but are also geographically contiguous is a further indication that this innovation is areal, i.e., contact-induced, rather than regularly inherited. Its presence in a small number of adjacent сшв languages only adds to this assumption.

In the following sections, we further substantiate these two claims, i.e., that FVL is a late innovation and that it is a contact-induced change. In Section 4, we consider the relative chronology of FVL with regard to other sound changes that characterize the Lower Kasai languages with FVL. In Section 5, we present a quantitative study of FVL in the languages concerned to better understand the specific kind of language contact scenario that could account for the current-day distribution of FVL in the Lower Kasai region.

In this section we consider the relative chronology of FVL with respect to other historical sound changes in the Lower Kasai area. There is evidence that FVL did not occur in noun and verb stems which underwent the intervocalic loss of a consonant or nasal consonant cluster. In other words, FVL did not target CVVshaped roots which evolved out of historical ${ }^{*} \mathrm{CVCV}$ and ${ }^{*} \mathrm{CVNCV}$, as shown in (12) with Ngwi data. Note that while intervocalic loss of $\mathrm{PB}{ }^{*} d$ is a mostly regular sound change in Ngwi, the loss of an intervocalic Рв ${ }^{*} b$ occurred only very sporadically. Similarly, while the loss of the merged Proto-wC в reflex ${ }^{*} k$ of рв 
velar stops ${ }^{*} k$ and ${ }^{*} g$ in $\mathrm{C} 2$ is very common throughout wCB (cf. Pacchiarotti and Bostoen, 2020), the loss of Proto-WCB * $k$ in $\mathrm{C}_{2}$ in Ngwi occurs in a very limited number of words.

(12) Ngwi B861 (WCB, own fieldwork data)

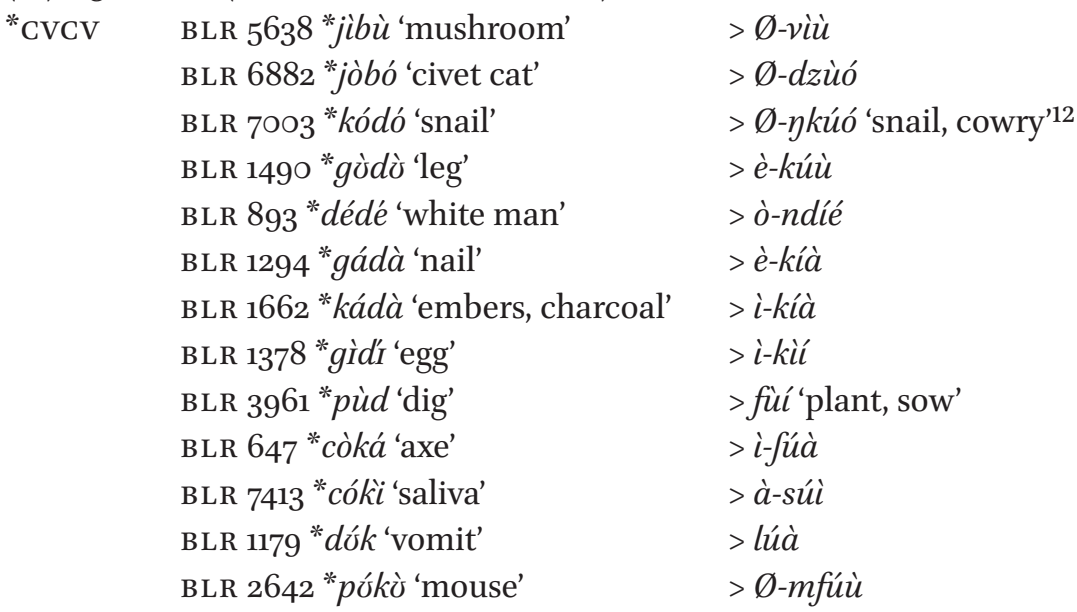

As can be seen from the reflexes in (12), there is no evidence that CVV structures originating from ${ }^{*} \mathrm{CVCV}$ structures further reduced to $\mathrm{CV}$. Even in languages where this were the case, we would not consider evolutions such as CVV $>\mathrm{CV}$ as instances of FVL based on our definition, because this development does not create closed syllables in word-final position. In terms of seriation of change, FVL must have happened after the loss of intervocalic segments in Lower Kasai languages targeted by this phenomenon. Otherwise, we would not end up with the observed synchronic outcomes. For instance, if the reflexes of BLR892 *dédé 'white man' or BLR2642 "pứkì 'mouse' had undergone first FVL and only afterwards the loss of $\mathrm{C} 2$, the chain of changes would not end up with the vowel sequences synchronically attested in Ngwi, e.g., we would have instead *dédé > déd > dé; "pớkì > fúk > fú fü. This chronology holds minimally for all WCB varieties which underwent FVL and the loss of a velar (cf. Pacchiarotti and Bostoen, 2020) or some other consonant in $\mathrm{C}_{2}$ position (see for instance Crane et al., 2011: 255-270 for Nzadi B865). Sources on the Lower Kasai CwB languages suggest that loss of $\mathrm{C} 2$ (including nasal consonant

12 Although beyond the scope of this paper, preliminary evidence from vowel deletion processes at the NP level suggests that the two-vowel sequences in the reflexes in (12) should be treated as a sequence of two vowel phonemes and not as phonetically complex single units (i.e., diphthongs). Two vowel sequences are extremely common in Ngwi and in other so-called "Bantu languages of the Forest" (Grégoire, 2003: 352). 
clusters) is not widespread in C83-C85 (cf. Vansina, 1959; Tete Wer Sey, 1975; Daeleman, 1977; Ngwamashi Kabandji-Bola Kamu, 1979).

The data in (13) illustrate CṼ̃ and CVV shapes resulting from historical ${ }^{*} \mathrm{CVNCV}$ shapes in Ngungwel B72a. In WC B, the loss of PB nasal consonant clusters in $\mathrm{C} 2$ position, especially ${ }^{*} n g$ and irregularly ${ }^{*} m b$, is widespread in several Teke varieties spoken in the Republic of the Congo; vowel nasalization only occurs in Ngungwel as the result of the loss of ${ }^{*} \mathrm{mb},{ }^{*} \mathrm{~m}$ and sometimes ${ }^{*} n d$ (Hombert, 1986; 1987; Paulian, 1994; Raharimanantsoa, 2012a; 2016). ${ }^{13}$

(13) Ngungwel B72a (wCB, Ruth Raharimanantsoa, p.c.)

\begin{tabular}{|c|c|}
\hline${ }^{*} \mathrm{CVNCV}$ & BLR 1719 *káng 'fry, roast' \\
\hline & BLR 1450 *gòngò 'back(bone)' \\
\hline & BLR 739 *cóngé 'moon, month' \\
\hline & BLR 242 *bimbà 'corpse' \\
\hline & $\begin{array}{l}\text { BLR } 2761 \text { *támbí 'sole, footprint' } \\
\text { BL } 2306 \text { *iàmbé 'God' }\end{array}$ \\
\hline
\end{tabular}

In Ngungwel B72a, FVL did not target syllable shapes such as CṼ̃ and CVv, but only CVCV (see Appendix). This is additional evidence for the proposed seriation of intervocalic consonant (and nasal consonant cluster) loss followed by FVL.

In sum, the relative chronology of FVL with regard to other diachronic sound shifts in the Lower Kasai indicates that it happened comparatively late and that it only targeted final vowels of minimally disyllabic roots which did not lose their $\mathrm{C}_{2}$ intervocalically.

In this section, we present the results of a quantitative study of lexical items targeted by FVL in each of the Lower Kasai languages displaying this phenomenon. These are in Table 1 where N/A means 'does not apply'. For each language variety in our sample, we linked a varying number of synchronic lexemes $(\sim 100$ to $\sim 500)$ to reconstructions in the BLR3 database (Bastin et al., 2002).

13 Only Pв * $n g$ gets lost in some wC в languages spoken in the DRC. These are Mfinu B83 and possibly other varieties spoken in the vast plateau northeast of Kinshasa, as well as all the languages belonging to the Kwa-Kasai north subgroup (Pacchiarotti et al., 2019), namely Tiene B81, Boma Yumu B8oz, North Boma B82, Mpe B821 and Nunu B822. In virtually all other шCB languages outside of the Kikongo Language Cluster, Рв nasal consonant clusters are simplified, e.g., * $\mathrm{NC}>\mathrm{N}$. In Mpiin B863 (KLC extended), the nasal resulting from this simplification is also lost and creaky voice develops on the remaining vowels perhaps as a compensatory strategy, e.g., BLR1332 *gàngà 'medicine man' > B863 ngắá. 


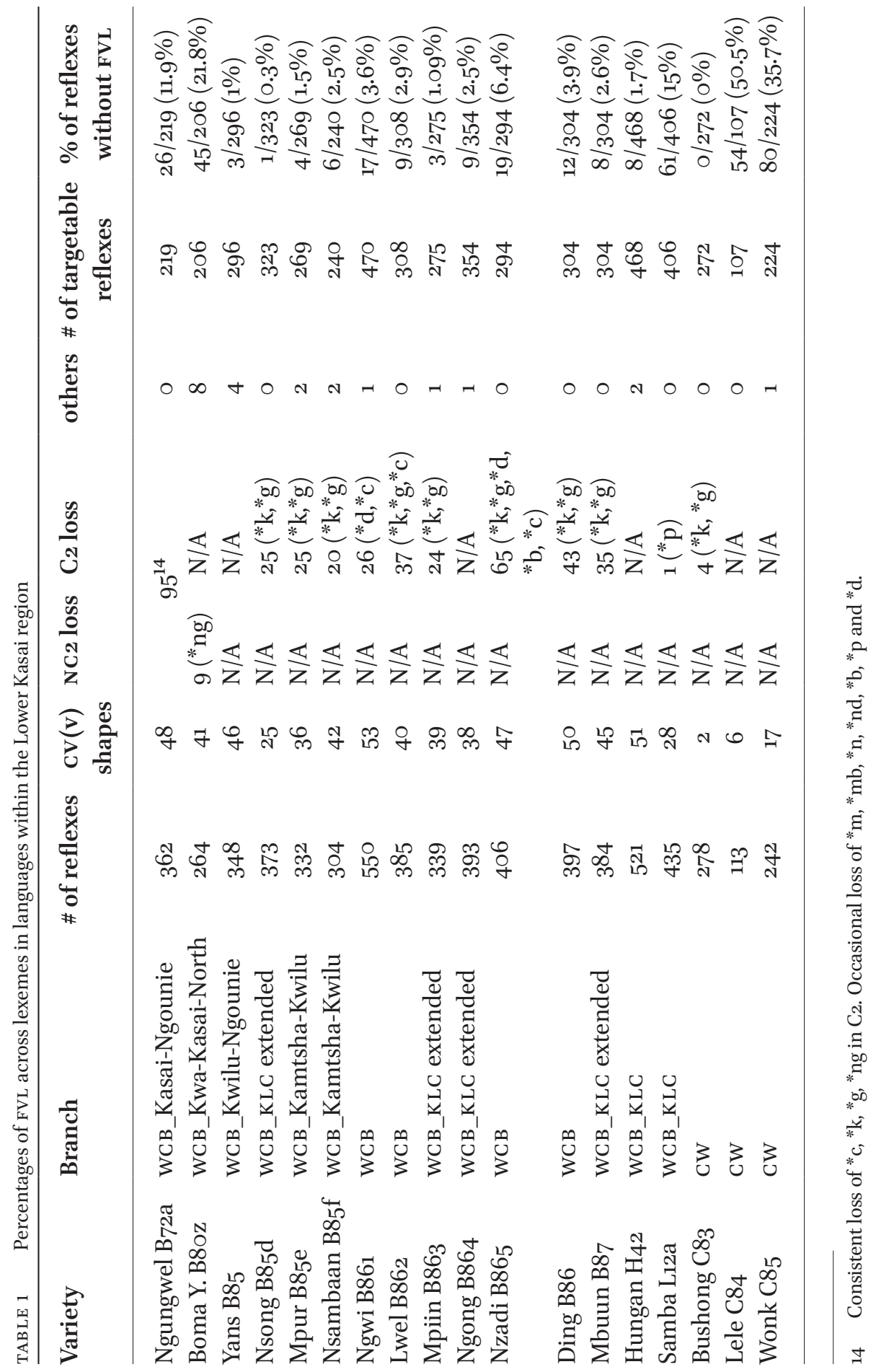


By linking reflexes to actual protoforms, we could rely on diachronic evidence to claim the presence vs. absence of a final vowel in the synchronic form of a given variety because we know to what syllable shape a given reflex goes back to. In the Appendix, we provide a list of 6o widespread BLR reconstructions with their corresponding reflexes to substantiate our claim that FVL occurs in all the varieties included in this study and that it is phonologically unconditioned (i.e., it occurs regardless of the manner of articulation of $\mathrm{C}_{1}, \mathrm{C}_{2}$ or $\mathrm{NC}_{2}$, the quality of $\mathrm{V}_{1}$ and/or $\mathrm{V}_{2}$ and the tone pattern of the reconstruction). Cognate sets in the Appendix are ordered according to the BLR protoform number (lower to higher) of which we believe they are a reflex. Each cognate set starts with the BLR protoform index number, form and meaning, followed by the synchronic reflexes we could identify. We mark both $\mathrm{H}$ and $\mathrm{L}$ tone as [á] and [à], respectively. Absence of tone on a reflex means that the original source does not note tone. We indicate the meaning of reflexes only if they differ with respect to the meaning(s) assigned to the corresponding protoform in BLR. The symbol '-' next to an alphanumeric code representing a variety means that the variety has a reflex of another protoform for a given concept. A question mark means lack of data.

After having gathered the biggest possible number of linked reflexes based on available materials, we systematically excluded from our counting all lexemes whose syllable shapes could not be targeted by FVL in each of the varieties in question (see columns cvv, $\mathrm{C}_{2}$ loss, NC2 loss in Table 1). This step requires language/branch-specific knowledge of diachronic sound changes. As can be seen in Table 1, several WCB varieties lose velars in $\mathrm{C}_{2}$, a sound change which creates CvV syllable shapes which are not suitable targets for FVL (cf. Section 4). Other ШСв varieties are more extreme in that they lose velars alongside consonants with other places of articulation (see e.g., Nzadi B865, Ngwi B861). We also excluded cases of reduplication and borrowing (see column Others in Table 1). After this step, we ended up with a language-specific variable number of lexemes with syllable shapes which could be targeted by FVL. We then proceeded to count the number of lexemes still displaying a final vowel in each of the varieties in our dataset. To uniformize the differing numbers of lexical tokens we could retrieve per language, we calculated the percentage over the total amount of lexemes per variety.

Figure 3 summarizes the results of our quantitative analysis. In Figure 3, percentages of FVL for each variety are represented by means of pie charts. 


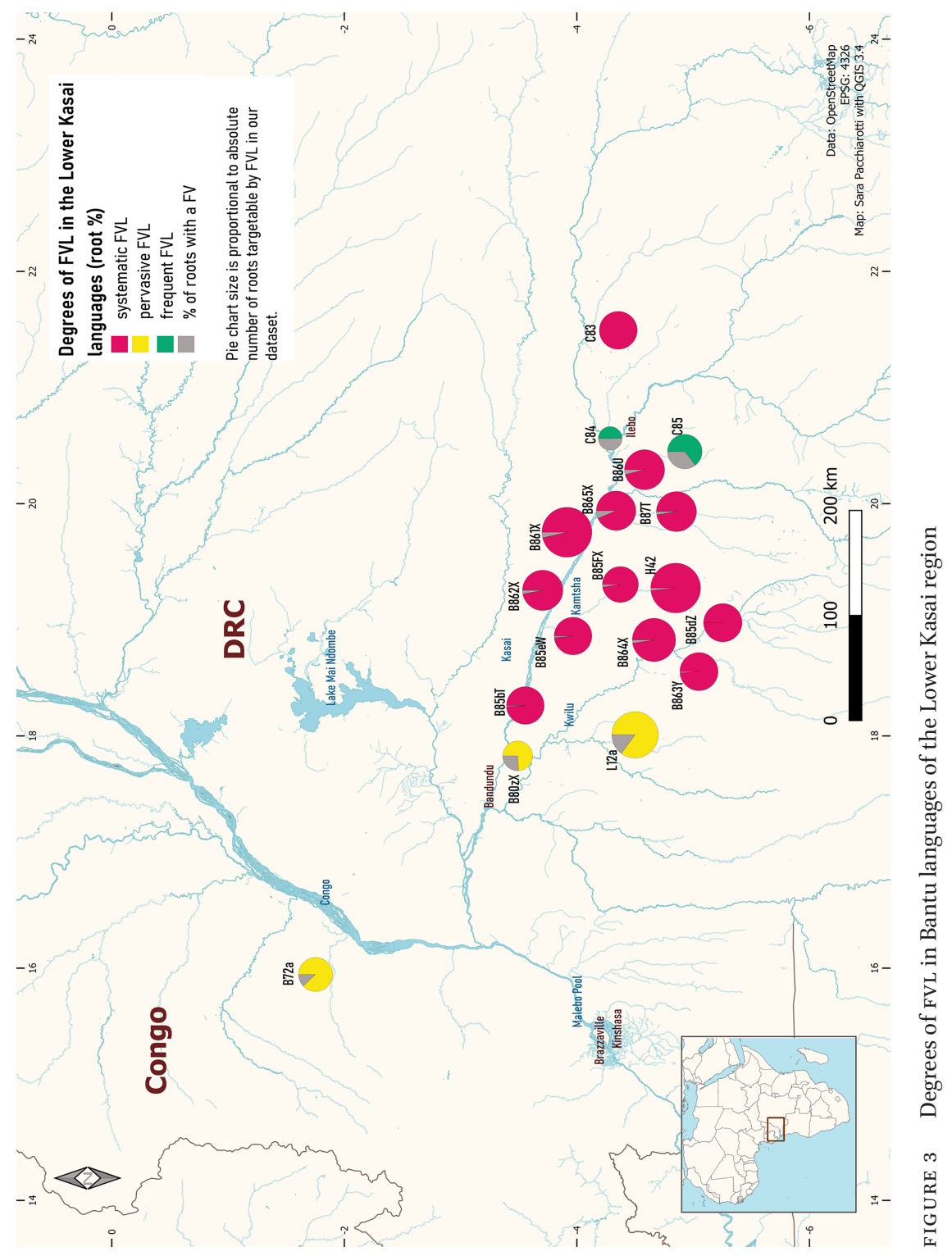


Based on the percentages in Table 1, we identify three "degrees" of FVL across the dataset.

Systematic FVL: languages with only o-6\% of lexemes having a final vowel, i.e., Yans B85, ${ }^{15}$ Nsong B85d, Mpur B85e, Nsambaan B85F, Ngwi B861, Lwel B862, ${ }^{16}$ Mpiin B863, Ngong B864, Nzadi B865, Ding B86, Mbuun B87, Hungan $\mathrm{H}_{42}$, and Bushong $\mathrm{C}_{3}$;

Pervasive FVL: languages with $10-30 \%$ of lexemes having a final vowel, i.e., Boma Yumu B8oz, ${ }^{17}$ Samba L12a, Ngungwel B72a; ${ }^{18}$

Frequent FVL: languages with $30-50 \%$ of lexemes having a final vowel, i.e., Lele C84, Wonk $\mathrm{C} 85 \cdot{ }^{19}$

Dialectal Diffusion and Substrate Influence in the History of FVL

In Sections 3-5, we gathered several pieces of evidence indicating that FVL in the Lower Kasai region emerged and spread as a contact-induced change. In this section, we review this evidence to assess which processes of language contact underlie its current-day distribution. We distinguish between two scenarios which we believe to have occurred sequentially in time, i.e., substrate influence and dialectal diffusion respectively.

We start with the process of dialectal diffusion. Our classification of the FVL phenomenon into three degree categories in Section 5 , i.e., systematic vs. pervasive vs. frequent, indicates that FVL is widespread in the Lower Kasai region, but that this phonological innovation did not affect the lexicon of all languages concerned in an equal way (see Figure 2). Only in the 'systematic FVL' languages did this sound shift consistently shorten all targetable lexical items, some rare

15 In Yans B85, Nsong B85d, Mpur B85e, Nsambaan B85F, Nzadi B865 and Mbuun B87 all lexemes with a final vowel (excluding borrowed nouns) are verb stems with a frozen derivational suffix, e.g., B85d kù-yáná 'be dry', B85e ù-yáná 'be dry', ${ }_{3} 85 \mathrm{~F}$ kàwáná, $\mathrm{B} 87$ kàwáná 'spread' (< BLR 8257 *jánam 'dry in the sun, be spread out'); B865 ò-kàysà 'collect, put together, fold, tie' (<BLR 1331 * gàng 'tie up'), ò-mònkà 'be visible, shine' (<BLR 2206 *món 'see').

16 In Ding B86, Lwel B862 and Ngong B864 most words with a final vowel are nouns and some

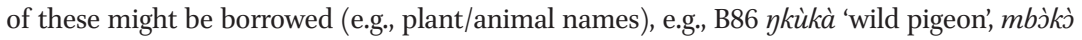
'forest antelope, sp., B862 kùké 'pigeon', B864 mpìndó 'millet' (<BLR 6702 *pòndó).

17 In Boma Yumu B8oz verb roots preserve a final vowel more often than noun roots.

18 In Ngungwel B72a, most items with a final vowel are verbs with a frozen derivational suffix as well as nouns where $V_{1}$ elides or is hardly audible yielding a CCV shape, e.g., $n d z z_{r} \hat{u}$ 'body' < BLR 1635 *jótò. In Ngungwel, reflexes of * $\mathrm{CV}$ and ${ }^{*} \mathrm{CVV}$ never lose their final vowel.

19 In Lele $\mathrm{C}_{4} 4$ and Wonk $\mathrm{C}_{5}$, all items with a final vowel belong to a syntactic category other than verbs, i.e., nouns, adjectives, numerals. 
exceptions notwithstanding, for instance loan words from languages not undergoing FVL such as Kikongo or Lingala, the main vehicular languages of the Lower Kasai region. As shown in Fig. 2, the 'systematic FVL' languages not only constitute the majority of the FVL languages, but also form a geographical cluster with regard to the two other types of FVL languages with the apparent exception of Bushong $\mathrm{C}_{3} 3$ to which we return below. The 'pervasive FVL' and 'frequent FVL' languages, in which considerably more lexical items have escaped the innovation, are mostly situated to the west and to the east of the 'systematic FVL' cluster. Ngungwel B72a is the most extreme western outlier, especially if we do not consider geographically intermediate Teke varieties such as Bwala B70y, Mosieno B76a, Wuumu B78 and Boma Nkuu B8ox, in which FVL sporadically occurs, but whose sources are far too insufficient for a statistically relevant quantitative analysis (cf. Section 3).

In other words, the 'systematic FVL' languages could be considered as the core of innovation in whose periphery the two other types of FVL languages are situated as instances of less systematic innovation. This kind of geographic pattern, i.e., a 'centrality vs. peripherality' (Trudgill, 2011: 7-8) or 'core vs. periphery' (Winford, 2003: 288, 348), is a classic in (historical) dialectology and has a long tradition in contact linguistics. More central languages constitute the center of innovation, while more peripheral languages are (more) conservative in that they resisted the change (more). In this sense, all 'no FVL' languages surrounding the Lower Kasai FVL languages form the most extreme periphery which remained untouched by the innovation.

Telling with regard to the 'core vs. periphery' pattern is that certain varieties of what we consider to be FVL languages do not attest FVL at all despite being situated at the margins of the Lower Kasai FVL isogloss. This is the case of the southern FVL languages Hungan $\mathrm{H}_{42}$ and Samba L12a, both members of the Kikongoid subgroup of the Kikongo Language Cluster (see Figure 2). Although we classify the Kipuka variety of Hungan considered here (see also Takizala, 1974) among the 'systematic FVL' languages, the Kwilu-Kimbata variety (see for example Batusisa Bibinda, 1972) did not undergo the innovation (cf. Bostoen and Koni Muluwa, 2011: 253-254). This also holds for Hungan's close relative Samba L12a, which we included in the 'pervasive FVL' languages. Unlike in the Kimafu variety included here (see also Van Acker, 2018), the innovation is entirely absent from more (south)eastern varieties of the language (cf. Van Acker, 2016).

The same is true for the сшв language Bushong $\mathrm{C}_{3}$, which is the easternmost 'systematic FVL' language, separated from the other languages of that type by two closely related 'frequent FvL' languages, i.e., Lele C84 and Wonk $\mathrm{C}_{5}$. The Bushong variety considered here is the central one spoken in 
Mushenge (DRC) described by Vansina (1959), who distinguishes northwestern and southern dialects (see also Vansina, 1958). Older sources describing the language, aka Kuba after the eponymous kingdom, consistently write lexical items with final vowels (cf. Brown-Edmiston, 1932; Maes, 1934). This could indicate that there are dialectal differences in terms of FVL. However, this could also just reflect evolving orthographic practices. This is very likely considering that Brown-Edmiston (1932: 6-7) notes that "[i]n a large number of words throughout the language the final vowel is never sounded except in certain constructions or unless the words are spoken slowly and distinctly or emphatically". ${ }^{20}$ On the other hand, Vansina (1974: 177) observes without providing further details that the loss of the final vowel is not systematic in all Bushong dialects and is absent from Lele C84 (possibly in a different variety than the one considered here). Hence, a dedicated dialectal survey of Bushong would be useful in this respect. For the time being, FVL in the wider Bushong area turns out to be less systematic than what the data from the central variety would lead one to believe at first sight. We elaborate below on the historical reasons evoked by Vansina (1974) to account for the systematicity of FVL in the central Bushong variety closely linked with the Kuba kingdom.

In sum, Bushong $\mathrm{C}_{3}$, Hungan $\mathrm{H}_{42}$ and Samba L12a can all be excluded from the FVL core, as each of these languages has varieties which escaped the innovation. As a consequence, the FVL core actually includes only eastern B8o languages. Given that the core vs. periphery pattern in the geographical distribution of FVL in the Lower Kasai languages suggests a classical scenario of dialectal diffusion (Andersen, 1988), the eastern B8o languages must have been the center of innovation or focal area from which this innovation gradually spread to more peripheral relic areas in the east, west and south. Because the FVL core stretches along the south bank of the Kasai River, the latter probably constituted a natural boundary to its northward diffusion.

The hypothesis that the center of innovation of FVL must have been along the south bank of the Kasai River in the DRC has been incipiently set forth by Vansina (1973-1974: 336-337), who argues that what he calls the "Lower Kwilu peoples" (i.e., our center of innovation) were at some point in history in a role of prestige and influenced their northern, eastern and western neighbors. As

20 The fact that Maes (1934) also writes vowels for B8o varieties, such as Ding B86 and Mbuun B87, equally suggests that it is indeed a matter of orthography or rather prescriptivism, especially if one considers that in almost contemporaneous dictionaries of B8o languages, such as those of Mertens (1939) and Swartenbroeckx (1948), final vowels are consistently omitted. 
discussed above, their influence did not extend so much to the north, but rather to the east, west and south. As for Bushong, Vansina (1974: 179-181) attributes the innovation to the cultural hero Shyaam aMbulangoong, a king of Mbuun origin, who would have conquered the Kuba kingdom around the 1640 os and subsequently reformed and enlarged it. Although his dynasty soon adopted the local language, the Mbuun way of speaking characterized by dropping final vowels became vested with prestige and gradually trickled from the capital to more remote parts of the kingdom. As Bushong was the language of communication between the central and local authorities within the kingdom, Vansina (1974: 181) interprets the range of the FVL phenomenon within the wider Kuba C80 group as a reflection of how far the royal power extended. This would explain why it is irregularly attested in languages such as Lele C84 and Wonk $\mathrm{C} 85$ and entirely absent from Ndengese $\mathrm{C} 81$ and Hendo C82. Hence, the Kuba kingdom constituted a secondary center of dialectal diffusion for FVL after it was introduced through a new dynasty from the Kwilu-Kasai region where this phonological innovation actually originated. This explains why Bushong is a 'systematic FVL' language that is geographically somewhat disconnected from the FVL core. In contrast to the contact-induced spread of noun prefix reduction in the KLC from the capital of the Kongo kingdom (cf. Bostoen and de Schryver, 2015), only a minor part of the current-day distribution of FVL can be accounted for as a prestige-driven diffusion from the capital of the Kuba kingdom.

In contrast to the Kuba area to the east of the FVL core, historical data to explain the dialectal diffusion of this innovation to the lands south (e.g., Hungan $\mathrm{H}_{42}$ and Samba L12a) and west (e.g., Ngungwel B72 and Boma Yumu $\mathrm{B} 8 \mathrm{oz}$ ) are unfortunately missing. Given the systematicity of the FVL in the eastern B8o core, dialectal diffusion also does not explain how it initially emerged there as a contact-induced sound change.

As we showed in Section 3, the B8o languages which constitute the FVL core are geographically clustered, but they do not form a genetic unit within the шсв branch of the Bantu family; quite the opposite. Their distribution zone between the Kwilu and Kasai Rivers is the area of highest linguistic diversity within ШСв and includes the branch's putative homeland between the Kamtsha and Kasai Rivers (Pacchiarotti et al., 2019). Given that FVL is absent from the remainder of WCB, it must have emerged after the major wCB subbranches had started to expand away from the homeland towards the Atlantic. As discussed in Section 4, the seriation of FVL with regard to other common sound changes in $\mathrm{B} 8 \mathrm{O}$ languages suggests that it is a relatively late innovation. Given that the B8o languages attesting FVL belong to distinct WCB subbranches, they cannot have inherited this phonological innovation from 
a most recent common ancestor. Moreover, given their geographic adjacency, it would be highly unlikely, and in contradiction with the law of parsimony (a.k.a. Occam's razor), to assume that they independently underwent it as a language-internal change. Therefore, exposure to a shared external source through language contact seems to us the most plausible explanation to account for a feature shared across languages spoken in the same area but belonging to distinct subgroups. If that feature is purely lexical, especially non-basic vocabulary, the most plausible scenario is borrowing through cultural contact between neighboring speech communities. Such exchange of loanwords may easily happen without bi- or multilingualism among the speakers in contact. For example, many loanwords from French, Portuguese, English and Dutch made it into WCB languages without most of their speakers having any command of those foreign languages (Kwenzi-Mikala, 1989; Yome Aya, 1997; Yengo-ki-Ngimbi, 2004; Elala Moke, 2008; Brinkman and Bostoen, 2018). However, if the shared feature is structural, especially phonological or syntactic, borrowing without bi- or multilingualism does not suffice as an explanation. In such a case, the contact-induced change points towards shift-induced interference or substrate influence (Thomason, 2006). The transfer of phonological features and rules between languages, if not through inheritance, is often considered to be highly constrained and to happen only through intense contact and a high degree of bilingualism (Winford, 2003: 54-56). This suggests partial acquisition of a target language by shifters (Thomason, 2008) or 'imposition' under 'source language agentivity' (Van Coetsem, 1988), i.e., L1 speakers leaving a structural impact on their L2, initially in the process of language acquisition and ultimately through language shift. In the case of FVL, substrate influence is all the more likely, because it concerns a phonological pattern and not actual phonemes. Although foreign sounds in borrowed vocabulary usually get nativized (Calabrese and Wetzels, 2009: 1), the integration of loan phonemes into the phonology of the recipient language may happen if there is widespread bilingualism in a society (Bondarko, 2000: 56; Dimmendaal, 2011: 182). The CwB language Ngombe C41, for example, started to acquire labial-velar stops through the massive adoption of Ubangi loanwords (Bostoen and Donzo, 2013). However, given that FVL systematically targets inherited Bantu vocabulary, large-scale borrowing of foreign vocabulary cannot account for its systematicity. ${ }^{21}$ This kind of systematicity rather points towards the imposition of a foreign phonological pattern on native Bantu vocabulary, i.e., non-Bantu speakers imposing closed final

21 In fact, we find virtually no non-Bantu lexical items in the lexicon of the Bantu languages considered in this paper with the notable exception of Lwel B862. 
syllables on Bantu languages due to incomplete language acquisition in the process of language shift. The shift of L2 speakers to L1 must have been considerably high for the foreign phonological pattern to be transmitted to the next generation of L1 speakers. Conceivably, several L1 and L2 were at play and the shifting process spanned several generations. However, if so, the extinct L2 varieties must have shared the tendency to closed syllables judging from the uniform phonological outcome of the language shift.

In contrast to the northern Bantu borderland, where Bantu languages are in touch with languages of all major African phyla, and the southern Bantu borderland, where they are in close connection with Khoisan, only Bantu languages are spoken in the current-day Lower Kasai region. If FVL was indeed induced by a non-Bantu substrate, the most likely candidates would be the 'pre-Bantu' languages of autochthonous hunter-gatherers of which no trace has been left (Bahuchet, 2012). In the FVL core area, no Central-African forager groups, aka 'Batwa' or 'Pygmies', have persisted. They do still exist in the neighboring Mai-Ndombe and Kasai provinces (von Wissman et al., 1891; Hiernaux, 1966; Omasombo Tshonda, 2019: 66). However, as far as the limited available sources show, the Bantu languages of those Batwa groups did not undergo FVL (cf. Motingea Mangulu, 2010; Chabiron et al., 2013). One might then wonder whether it is plausible to attribute FVL to the integration of language shifting hunter-gatherers into Bantu B8o speech communities if the Bantu languages of today's closest relic hunter-gatherer groups do not manifest the phenomenon. On the other hand, it is completely unknown how high the linguistic diversity was among autochthonous hunter-gatherers before they shifted to Bantu languages. Strikingly, zone A languages undergoing FVL (cf. Section 3) also have hunter-gatherer groups in their close vicinity. Hence, substrate influence from pre-Bantu hunter-gatherer languages seems a possible scenario to account for the development of FVL in the region. This would imply a relatively massive shift of hunter-gatherers to Bantu B8o languages as well as the assimilation of their speakers into the Bantu speech communities concerned. Although it is impossible to substantiate this hypothesis with hard linguistic evidence, new evolutionary genetic data might shed light on this question.

In sum, we propose here a two-stage evolution for the development of FVL in the Lower Kasai region. This relatively late innovation originated as the outcome of substrate interference, most likely from pre-Bantu hunter-gatherer languages, in the FVL B8o core, and subsequently spread from that focal area of innovation to more peripheral areas through a process of dialectal diffusion. 


\section{Conclusions}

In this article, we characterized FVL in the Lower Kasai region of the DRC as the historical loss of the word-final vowel segment in the reflexes of polysyllabic nominal and verbal stems reconstructed with the shape * $\mathrm{CV}(\mathrm{N}) \mathrm{CV}$ (cf. Bastin et al., 2002). Unlike in other parts of the Bantu domain, FVL in the Lower Kasai region was not a phonologically constrained sound change. The change targeted all words with a suitable syllable structure regardless of the manner and place of articulation of consonants, the quality of vowels and the tone pattern of the reconstructed stem.

We demonstrated that FVL must have taken place after the loss of certain intervocalic consonants in some WСв languages spoken around and southeastwards of Bandundu (city) along the Kasai River in the current DRC province of the Kwilu, namely: Yans B85, Nsong B85d, Mpur B85e, Nsambaan B85F, Ding B86, Ngwi B861, Lwel B862, Mpiin B863, some varieties of Ngong B864, Nzadi B865 and Mbuun B87. In these varieties (and in some varieties of Bushong C83), this diachronic phonological process created word final closed syllables $\left({ }^{*} \mathrm{CVCV}>\mathrm{CVC}\right)$ in all phonotactically suitable environments.

As these FVL languages belong to distinct subgroups but are geographically clustered in the шсв homeland region, we argued that they must have acquired this feature through language contact. Due to the systematicity of the innovation and the fact that it concerns a structural phonological pattern, we posited that it must be the outcome of substrate interference from language shifters incompletely acquiring their new language(s). Although we lack hard evidence to substantiate this claim, we propose that non-Bantu-speaking hunter-gatherers massively shifting - either from the same or from different non-Bantu L1 - to one or several Bantu B8o L2 may have initiated this sound change. If this relatively late innovation was indeed induced through contact with autochthonous hunter-gatherer communities, this could indicate that interactions between these and migrating Bantu-speakers were initially rather limited and became gradually more intensive once the newcomer groups were well settled and started to have an increasing impact on the environment (cf. Marks et al., 2015). As conclusive linguistic evidence to prove this hypothesis has vanished, only new evolutionary genetic data can help us assess its validity.

Once FVL was firmly rooted in the eastern B8o core area, the innovation spread from this epicenter as a "dialectally-diffused" contact-induced change to the geographically contiguous WCB varieties Boma Yumu B8oz, Hungan $\mathrm{H}_{42}$, and Samba L12a and to the CwB varieties Bushong B83, Lele C84 and Wonk C85. 


\section{Acknowledgements}

We wish to thank Hilde Gunnink (BantUGent) and an anonymous reviewer for their helpful feedback on an earlier draft of this article. We are indebted to Ruth Raharimanantsoa from siL Congo for providing us with the Ngungwel B72a data for this study. The usual disclaimers apply. The research for this article was funded by a Consolidator's Grant $\left(\mathrm{n}^{\circ}{ }^{724275}\right)$ of the European Research Council (ERC) under the European Union's Horizon 2020 research and innovation program, granted to the last author. The first author also acknowledges the support of the FWO (Fonds Wetenschappelijk Onderzoek Vlaanderen) postdoctoral fellowship $\mathrm{n}^{\circ} 12 \mathrm{ZV}_{721 \mathrm{~N}}$.

\section{References}

Andersen, H. 1988. Center and Periphery: Adoption, Diffusion, and Spread. In J. Fisiak (ed.), Historical Dialectology: Regional and Social, 39-83. Berlin, New York, Amsterdam: Mouton De Gruyter.

Bahuchet, S. 2012. Changing language, remaining Pygmy. Human Biology 84: 11-43.

Bastin, Y., A. Coupez and M. Mann. 1999. Continuity and Divergence in the Bantu Languages: Perspectives from a Lexicostatistic Study. Tervuren: Royal Museum for Central Africa.

Bastin, Y., A. Coupez, E. Mumba and T.C. Schadeberg (eds.). 20o2. Bantu Lexical Reconstructions 3. Tervuren: Royal Museum for Central Africa, online database: linguistics.africamuseum.be/BLR3.html (last accessed November 28, 2017).

Batusisa Bibinda, L. 1972. Essai d'une morphologie comparée des formes nominales et pronominales des langues hungana et piin. Lubumbashi: Université nationale du Zaïre, mémoire.

Bollaert, F. 2019. A Historical-Comparative Study of the Noun Class Systems in the KasaiNgounie (Extended) Languages (Bantu B50-70, B81-84). Ghent: Ghent University, MA thesis.

Bondarko, L.V. 20oo. Language contacts: phonetic aspects. In D. Gilbers, J. Nerbonne and J. Schaeken (eds.), Languages in Contact, 55-65. Amsterdam, Atalanta: Rodopi.

Bostoen, K., B. Clist, C. Doumenge, R. Grollemund, J.-M. Hombert, J. Koni Muluwa, and J. Maley. 2015. Middle to Late Holocene Paleoclimatic Change and the Early Bantu Expansion in the Rain Forests of West Central-Africa. Current Anthropology 56: $354-384$.

Bostoen, K. and G.-M. de Schryver. 2015. Linguistic Innovation, Political Centralization and Economic Integration in the Kongo Kingdom: Reconstructing the Spread of Prefix Reduction. Diachronica 32: 139-185. 
Bostoen, K. and G.-M. de Schryver. 2018a. Langues et évolution linguistique dans le royaume et l'aire kongo. In B. Clist, P. de Maret and K. Bostoen (eds.), Une archéologie des provinces septentrionales du royaume Kongo, 51-55. Oxford: Archaeopress.

Bostoen, K. and G.-M. de Schryver. 2018b. Seventeenth-Century Kikongo Is Not the Ancestor of Present-Day Kikongo. In K. Bostoen and I. Brinkman (eds.), The Kongo Kingdom: The Origins, Dynamics and Cosmopolitan Culture of an African Polity, 6o102. Cambridge: Cambridge University Press.

Bostoen, K. and J.-P. Donzo. 2013. Bantu-Ubangi Language Contact and the Origin of Labial-Velar Stops in Lingombe (Bantu, C41, D RC). Diachronica 30: 435-468.

Bostoen, K. and J. Koni Muluwa. 2011. Vowel split in Hungan (Bantu H42, Kwilu, DRC): A contact-induced language-internal change. Journal of Historical Linguistics 1: 247-268.

Bostoen, K. and J. Koni Muluwa. 2014. Umlaut in the Bantu B70/80 languages of the Kwilu (DRC). Transactions of the Philological Society 112: 209-230.

Bostoen, K. and L. Mundeke. 2011. The Causative/Applicative Syncretism in Mbuun (Bantu B87, DRC): Semantic Split or Phonemic Merger? Journal of African Languages and Linguistics 32: 179-218.

Brinkman, I. and K. Bostoen. 2018. 'To Make Book': A Conceptual Historical Approach to Kongo Book Cultures (16th-19th century). In K. Bostoen and I. Brinkman (eds.), The Kongo Kingdom: The Origins, Dynamics and Cosmopolitan Culture of an African Polity, 216-234. Cambridge: Cambridge University Press.

Brown-Edmiston, A. 1932. Grammar and dictionary of the Bushonga or Bukuba language as spoken by the Bushonga or Bukuba tribe who dwell in the Upper Kasai District, Belgian Congo, Central Africa. Luebo: Wilson.

Burssens, N. 1999. Dictionnaire français-buma. Bandundu: Centre d'Etudes Ethnologiques de Bandundu.

Calabrese, A. and W.L. Wetzels. 2009. Loan phonology: Issues and controversies. In A. Calabrese and W.L. Wetzels (eds.), Loan Phonology, 1-10. Amsterdam, Philadelphia: John Benjamins.

Chabiron, C., S. Gally and D. Demolin. 2013. Les parlers pygmées du bassin équatorial du Congo. Géolinguistique 14: 125-144.

Cheucle, M. 2008. Vers une description de la langue bekwel (A85b) du Gabon: approche synchronique, approche diachronique. Lyon: Université Lumière Lyon 2, mémoire de master.

Cheucle, M. 2014. Etude comparative des langues makaa-njem (bantu A8o): phonologie, morphologie, Lexique. Vers une reconstruction du proto-A8o. Lyon: Université Lumière Lyon 2, thèse de doctorat.

Crane, T.M., L.M. Hyman and S. Nsielanga Tukumu. 2011. A Grammar of Nzadi (B.865) A Bantu Language of the Democratic Republic of Congo with an Appendix of ProtoBantu - Nzadi Sound Correspondences by Clara Cohen. Berkeley: University of California Publications. 
Daeleman, J. 1977. A Comparison of Some Zone B Languages in Bantu. Africana Linguistica 7: 93-144.

de Schryver, G.-M., R. Grollemund, S. Branford and K. Bostoen. 2015. Introducing a State-of-the-Art Phylogenetic Classification of the Kikongo Language Cluster. Africana Linguistica 21: 87-162.

Dibata Mimpya, I. 1979. Esquisse grammaticale de la langue tsong: phonologie et morphologie. Lubumbashi: Université de Lubumbashi, mémoire de licence.

Dimmendaal, G. 2011. Historical Linguistics and the Comparative Study of African Languages. Amsterdam, Philadelphia: John Benjamins.

Ebalantshim Masuwan. 1980. Esquisse grammaticale de la langue idiy à Káantsa. Lubumbashi: Université Nationale du Zaïre, M.A.

Elala Moke, J.-J. 2008. Esquisse sémantique des emprunts français en ngwi. Mangai: Institution Supérieur Pédagogique Bandundu, Extension de Mangai, travail de fin d'étude de gradué.

Goemaere, A. 1984. Grammaire du londengese. Bandundu: Centre d'Etudes Ethnologiques de Bandundu.

Grégoire, C. 2003. The Bantu Languages of the Forest. In D. Nurse and G. Philippson (eds.), The Bantu Languages, 349-370. London, New York: Routledge.

Grollemund, R., S. Branford, K. Bostoen, A. Meade, C. Venditti, and M. Pagel. 2015. Bantu Expansion Shows That Habitat Alters the Route and Pace of Human Dispersals. Proceedings of the National Academy of Sciences of the United States of America 112: 13296-13301.

Guthrie, M. 1953. The Bantu Languages of Western Equatorial Africa (Handbook of African languages). London, New York: Oxford University Press for the International African Institute.

Guthrie, M. 196o. Teke radical structure and Common Bantu. African language studies 1:1-15.

Guthrie, M. 1967. Comparative Bantu: An Introduction to the Comparative Linguistics and Prehistory of the Bantu languages. Volume 1: The Comparative Linguistics of the Bantu Languages. London: Gregg International.

Guthrie, M. 1968. Notes on Nzebi (Gabon). Journal of African Languages 7: 101-129.

Guthrie, M. 1971. Comparative Bantu: An Introduction to the Comparative Linguistics and Prehistory of the Bantu languages. Volume 2: Bantu Prehistory, Inventory and Indexes. London: Gregg International.

Harford, C. and G.B. Malambe. 2015. Optimal Register Variation: High Vowel Elision in siSwati. Southern African Linguistics and Applied Language Studies 33: 343-357.

Heath, T. 2003. Basaá (A43). In D. Nurse and G. Philippson (eds.), The Bantu Languages, 335-348. London, New York: Routledge.

Hedinger, R. 2006. The Manenguba languages (Bantu A.15, Mbo cluster) of Cameroon. London, New York: Routledge. 
Hiernaux, J. 1966. Les Bushong et les Cwa du royaume Kuba (Congo-Kinshasa): Pygmées, Pygmoïdes et pygméisation; anthropologie, linguistique et expansion bantoue. Bulletins et Mémoires de la Société d'Anthropologie de Paris 9: 299-336.

Hombert, J.-M.1986. The developmnent of nasalized vowels in the Teke language group. In K. Bogers, H. van der Hulst and M. Mous (eds.), The phonological representation of suprasegmentals, 359-379. Dordrecht: Mouton De Gruyter; Foris.

Hombert, J.-M. 1987. Phonetic conditioning for the development of nasalization in Teke. Pholia 2: 85-93.

Hoover, J.J. 1978. The seduction of Ruwej: reconstructing Ruund history (the nuclear Lunda; Zaire, Angola, Zambia). New Haven: Yale University, PhD dissertation.

Hyman, L. 2019. Segmental Phonology. In M. Van de Velde, K. Bostoen, D. Nurse and G. Philippson (eds.), The Bantu Languages (Second Edition), 128-149. Oxford: Routledge.

Janssens, B. 1982. Phonologie historique du basaa (A43). Bruxelles: Université libre de Bruxelles, mémoire de licence spéciale.

Janssens, B. 1993. Doubles réflexes consonantiques: quatre études sur le bantu de zone A (bubi, nen, bafia, ewondo). Bruxelles: Université libre de Bruxelles, thèse de doctorat.

Khang Levy, N.-m.s. 1979. Eléments de grammaire morphologique de la langue lwel. Lubumbashi: Université Nationale du Zaïre, mémoire de licence.

Kitoko Mufanga, D. 1978. Contribution à la phonologie ding. Lubumbashi: Université nationale du Zaïre, travail de fin de cycle de graduat.

Koni Muluwa, J. 2014. Petit lexique français-anglais-nsambaan et nsambaan-françaisanglais (parlers de Kikongo et Kwilumpia). Ms. Gand: Université de Gand, Centre d'études bantoues (BantUGent), projet KwiluBantu (http://www.kwilubantu. ugent.be/).

Koni Muluwa, J. 2015. Petit lexique français-anglais-nsong et nsong-français-anglais (parlers de Kipuka). Ms. Gand: Université de Gand, Centre d'études bantoues (BantUGent), projet KwiluBantu (http://www.kwilubantu.ugent.be/).

Koni Muluwa, J. and K. Bostoen. 2012. La diphtongaison dans les langues bantu B70-80 (Bandundu, RDC): typologie et classification historique. Africana Linguistica 18: $355-386$.

Koni Muluwa, J. and K. Bostoen. 2015. Lexique comparé des langues bantu du Kwilu (République démocratique du Congo). Cologne: Rüdiger Köppe.

Kwenzi-Mikala, J.T. 1989. Contribution à l'analyse des emprunts nominaux du yipunu au français. Pholia 4: 157-170.

Lovestrand, J. 2011. Notes on Nyokon phonology (Bantu A.45, Cameroon). Yaoundé: SIL Cameroon.

Maes, J. 1934. Vocabulaire des populations de la region du Kasai-Lulua-Sankuru d'apres les observations de M. Achten. Journal de la Société des Africanistes 4: 209-268. 
Maho, J.F. 2009. NUGL Online: The Online Version of the New Updated Guthrie List, a Referential Classification of the Bantu Languages (4 Juni 20o9). Online file: http:// goto.glocalnet.net/mahopapers/nuglonline.pdf.

Marks, S.J., F. Montinaro, H. Levy, F. Brisighelli, G. Ferri, S. Bertoncini, C. Batini, G.B.J. Busby, C. Arthur, P. Mitchell, B.A. Stewart, O. Oosthuizen, E. Oosthuizen, M.E. D'Amato, S. Davison, V. Pascali, and C. Capelli. 2015. Static and moving frontiers: the genetic landscape of Southern African Bantu-speaking populations. Molecular Biology and Evolution 32: 29-43.

Mbwetete, E. 1984. Eléments de la phonologie et de la morphologie mpur. Kinshasa: Institut Pédagogique National, mémoire de licence.

Medjo Mvé, P. 1997. Essai sur la phonologie panchronique des parlers fang du Gabon et ses implications historiques. Lyon: Université Lumière-Lyon2, PhD dissertation.

Meeussen, A.E. 1952. Esquisse de la langue ombo (Maniema-Congo belge) (Annales du Musée royal du Congo belge). Tervuren: Musée royal du Congo belge.

Meinhof, C. and N.J. van Warmelo (eds.). 1932. Introduction to the Phonology of the Bantu Languages Being the English Version of "Grundriss Einer Lautlehre Der Bantusprachen" by Carl Meinhof, Translated, Revised and Enlarged in Collaboration with the Author and Dr. Alice Werner by N. J. Van Warmelo. Dietrich Reimer/Ernst Vohsen, published under the auspices of The International Institute of African Languages and Cultures, The Carnegie Corporation of New York, and The Witwatersrand Council of Education, Johannesburg.

Mertens, J. 1939. Les Badzing de la Kamtsha. Troisième Partie: Dictionnaire idzingfrançais suivi d'un aide-mémoire français-idzing. Bruxelles: Librairie Falk fils.

Motingea Mangulu, A. 1990. Esquisse du parler des Ohendo. Annales Aequatoria 11: 115-152.

Motingea Mangulu, A. 2010. Aspects des parlers minoritaires des lacs Tumba et Inongo: contribution à l'histoire de contact des langues dans le bassin central congolais. Tokyo: ILCAA, Tokyo University of Foreign Studies.

Mous, M. 2003. Nen (A44). In D. Nurse and G. Philippson (eds.), The Bantu Languages, 283-3o6. London, New York: Routledge.

Mufwene, S. 1973. The Segmental Phonemes of Yansi and English. A Contrastive Study, with a Brief Outline of the Most Outstanding Phonological Interferences of Yansi in English. Lubumbashi: National University of Zaire, MA thesis.

Mukash Kalel, T. 1982. Le kanyok, langue bantoue du Zaïre: phonologie, morphologie, syntagmatique. Paris: Université Sorbonne nouvelle, Paris III, PhD dissertation.

Mula, E. 1977. Esquisse de grammaire kiding munken: phonologie et morphologie (parler de Bantsiona). Lubumbashi: Université Nationale du Zaïre, mémoire de licence.

Mundeke, L. 1979. Esquisse grammaticale de la langue mbúún (parler de Éliob). Lubumbashi: Université Nationale du Zaïre, mémoire de licence. 
Mundeke, L. 2011. Etude morphosyntaxique de la langue mbuun (B87) (parler d'Elyob). Lubumbashi: Université de Lubumbashi.

Nash, J.A. 1992. Aspects of Ruwund Grammar. Urbana-Champaign: University of Illinois, $\mathrm{PhD}$ dissertation.

Nguma-Nanzioke. 1983. Le yanzi et le proto-bantu. Kinshasa: Institut Pedagogique National, M.A.

Ngwamashi Kabandji-Bola Kamu, E. 1979. Equisse morphologique du luhilel: formes nominales et pronominales. Kinshsasa: Institut Pédagogique National, Université Nationale du Zaïre, travail de fin d'études.

Ngwamashi Kabandji-Bola Kamu, E. 1981. Etude confrontative des formes verbales du français et du luhileel. Kinshsasa: Institut Pédagogique National, Université Nationale du Zaïre, mémoire de licence.

Njantcho Kouagang, E. 2018. A Grammar of Kwakum. Paris: INALCO, PhD dissertation. Nsuka Nkutsi, F. 199o. Note sur les parlers teke du Zaïre. Pholia 5: 147-173.

Odden, D. 2015. Bantu Phonology. Oxford Handbooks Online. Oxford: Oxford University Press. http://www.oxfordhandbooks.com/view/10.1093/oxfordhb/ 9780199935345.001.00o1/oxfordhb-9780199935345-e-59.

Omasombo Tshonda, J. (ed.). 2019. Mai-Ndombe. Mosaïque de peuples établie sur un patrimoine naturel. Tervuren: Musée royal de l'Afrique centrale.

Pacchiarotti, S. and K. Bostoen. 2020. The Proto-West-Coastal Bantu Velar Merger. Africana Linguistica 26: 139-195.

Pacchiarotti, S., N. Chousou-Polydouri and K. Bostoen. 2019. Untangling the WestCoastal Bantu Mess: Identification, Geography and Phylogeny of the Bantu B50-80 Languages. Africana Linguistica 25: 155-229.

Paulian, C. 1994. Nasales et nasalisation en ygùngwèl, langue bantu du Congo. Linguistique africaine 13: 83-129.

Raharimanantsoa, R. 2012a. Aspects of phonology in Eboo-Nzikou (Bantu B74). Gothenburg: University of Gothenburg, preparatory research course paper.

Raharimanantsoa, R. 2016. Réduction syllabique, rallongement compensatoire et syllabes trimoraïques en engungwel (bantou B72a). Journal of West African Languages 43: 61-98.

Ross, M. 2003. Diagnosing prehistoric language contact. In R. Hickey (ed.), Motives for language change, 174-198. Cambridge: Cambridge University Press.

Ross, M. 2013. Diagnosing Contact Processes from their Outcomes: The Importance of Life Stages. Journal of Language Contact 6: 5-47.

Rottland, F. 1970. Die Verbformen des Yanzi. Leiden: Rijksuniversiteit te Leiden, PhD dissertation.

Rottland, F. 1977. Reflexes of Proto-Bantu Phonemes in Yanzi (B85). Africana Linguistica 7: $375^{-}-396$. 
Swartenbroeckx, P. 1948. Dictionnaire kiyansi ou kiyei, langage des bayansi ou bayey de territoire de Banningville (district du Lac Léopold II) au Congo Belge. Ms. Bruxelles.

Takizala, A. 1974. Studies in the grammar of Kihungan. San Diego: University of California, PhD dissertation.

Tete Wer Sey, I.K. 1975. Eléments de grammaire wóngo (wónk) C85: Phonologie et morphologie. Lubumbashi: Université nationale du Zaïre, mémoire de licence.

Thomason, S.G. 2006. Language change and language contact. In K. Brown (ed.), The Encyclopedia of Language and Linguistics, 2nd edn, 339-346. Boston: Elsevier.

Thomason, S.G. 2008. Social and Linguistic Factors as Predictors of Contact-Induced Change. Journal of Language Contact, Thema 2: 42-56.

Trudgill, P. 2011. Sociolinguistic typology. Social Determinants of Linguistic Complexity. Oxford: Oxford University Press.

Van Acker, S. 2016. De fonologie van het Kitsamba (Bantoe, L12a, DR Congo) vanuit een synchroon en diachroon perspectief. Gent, BA thesis.

Van Acker, S. 2018. A Pilot Study of Kisamba (Bantu, L12a, DRC): Phonology, Morphology, Wordlist and Some Texts. Ghent: Ghent University, MA thesis.

Van Acker, S. and K. Bostoen. 202O. Inheritance and Contact in the Genesis of Gisamba (Bantu, L12a, DRC): A Diachronic Phonological Approach. Linguistique et Langues Africaines 6: 73-130.

Van Coetsem, F. 1988. Loan Phonology and the Two Transfer Types in Language Contact. Dordrecht: Foris.

van de Velde, M.L.O. 2008. A Grammar of Eton. Berlin: Mouton De Gruyter. van der Veen, L. 2003. The B3o Language Group. In D. Nurse and G. Philippson (eds.), The Bantu Languages, 371-391. London, New York: Routledge.

Vansina, J. 1958. Taalgeografische toestand in het Kuba-gebied. Aequatoria 21: 1-4.

Vansina, J. 1959. Esquisse de grammaire bushong. Tervuren: Musée royal du Congo belge.

Vansina, J. 1973-1974. Probing the past of the Lower Kwilu peoples (Zaire). Paideuma 19-20: $332-364$.

Vansina, J. 1974. Les langues bantoues et l'histoire: le cas kuba. In H.J. Deschamps (ed.), Perspectives nouvelles sur le passé de l'Afrique noire et de Madagascar: Mélanges offerts à Hubert Deschamps, 171-184. Paris: Publications de la Sorbonne.

Vansina, J. 1995. New Linguistic Evidence and the Bantu Expansion. Journal of African History 36: 173-195.

Vincke, J.L. 1966. Aspects de la phonologie et de la morphologie de la langue lunda (ruund). Elisabethville: Université officielle du Congo, thèse de doctorat. 
von Wissman, H., L. Wolf, C. von François and H. Müller. 1891. Im Innern Afrikas: die Erforschung des Kassai während der Jahre 1883, 1884 und 1885. Leipzig: Brockhaus.

Watters, J.R. 2003. Grassfields Bantu. In D. Nurse and G. Philippson (eds.), The Bantu Languages, 225-256. London, New York: Routledge.

Winford, D. 2003. An introduction to contact linguistics (Language in society 33). Malden: Blackwell.

Yengo-ki-Ngimbi, A.-É. 2004. Emprunts portugais et français en kiyombe, langue kongo du Bas-Congo. In P. Mabiala Mantuba-Ngoma (ed.), La nouvelle histoire du Congo: mélanges eurafricains offerts à Frans Bontinck, c.i.c.m., 167-199. Paris: L'Harmattan. Yome Aya, A. 1997. Etude sémantique des emprunts lexicaux du français en mbuun B87: Parler de Ntango, secteur d'Imbongo. Kikwit: IsP de Kikwit, mémoire de licence.

\section{Appendix: Cognate Series Proving Phonologically Unconditioned FVL in the Lower Kasai Bantu Languages}

(1) BLR 93 *bàndà 'valley': B72a?, B8oz -, B85b -, B85d mó-bân, B85e-, B85F má-bán, B861-, B862 -, B863 -, B864 mó-bân, B865 -, B86 mu-bààn, B87 u-bân, C83 là-bààn, C84?, C85 rù-bààntá, $\mathrm{H}_{42}$ kí-wànd, L12a mó-wàndà.

(2) BLR 212 *bíndà 'calabash': B72a -, B8oz -, B85b mbiin, B85d mbîn, B85e mbín, B85F mbyín, B861 -, B862 mbín, B863 mbîn, B864, B865 mbín, B86U mbiín, B87 mbîn, C83 mbyéén, C84 mbéndà, C85 mpéntá, $\mathrm{H}_{42}$ mùbin 'calabash nutmeg', L12a - .

(3) BLR 265 *bòmbó 'forehead, bridge of nose, nose': B72a -, B8oz mbwòm, B85b mbj̀jm, B85d mbôm, B85e mbó:m, B85F mbóóm, B861 Ø-mbwǒm, B862 bwǎm, B863 mbôm, B864 mbôm, B865 m-bwǒm, B86U mbǒm

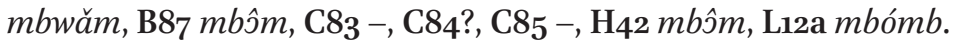

(4) BLR 275 *bóngó 'knee': B72a búó, B8oz i-bwó, B85b i-bón, B85d è-bóng, B85e bwáy, B85F è-bón, B861 i-bwón, B862 bóy, B863 bơ , B864 bón, $\mathrm{B} 865$ imón, B86 è-bón, B87 i-bón, C83 i-yóóndj, C84 i-mòngò, C85 i-mónkó, $\mathrm{H}_{42}$ bón, L12a bòng.

(5) BLR 346 * bơt 'bear child, fruit': B72a burû 'give birth' B8oz ò-búra, B85b bót 'bear child', B85d kò-bútúk 'be born', B85e?, B85F kà-búr 'raise (an animal)', B861wûr, B862 bwár 'give birth', B863?, B864 kò-bútúk 'be born', B865 ò-bûr 'give birth', B86 bór, B87 kà-bór, C83 à-bót, C84?, C85, $\mathrm{H}_{42}$ kùbút 'give birth', L12a gù-búd 'give birth'.

(6) BLR $35^{1}$ *bớtò 'seed': B72a $e-b^{u} r \hat{u}, \mathbf{B} 80 z-, \mathbf{B} 85 \mathbf{b}$ lì-bór, B85d mbút, B85e mmbór, B85F mbúr, B861 -, B862 là-búr, B863 ṁbúr, B864 lò-bút, B865 -, B86 mbúr, B87 là-bór, C83 -, C84?, C85 rù-mpót, $\mathrm{H}_{42}$ mbút, L12a -. 
(7) BLR 406 *ádá 'feather': B72a è-sál, B80z lè-sál, B85b lè-sál', B85d lì-sál, B85e lì-sál, B85F là-sál, B861 è-síà, B862 sál, B863 lù-ntsál, B864 l̀̀-sál, B865 غ̀-sáá, B86 lù-sál, B87 là-sál, C83?, C84 hàlà, C85 ru-sara, $\mathrm{H}_{42}$ lù-sál,

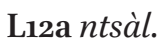

(8) BLR 475 *àngà 'island': B72a?, B8oz ì-sàà, B85a è-sàà 'oasis', B85d ̀̀sàyży, B85e isày àda, B85F -, B861 -, B862 kà-sày, B863 kì-sà:, B864 kغ̀sa:, $\mathbf{B} 865$ è-sày, $\mathrm{B} 86$ è-sày, $\mathrm{B} 87$ i-sày, C83 i-fàày, C84?, C85 isàànké, $\mathrm{H}_{42}$ kì-săng, L12a săng.

(9) BLR 479 *càngò 'news': B72a ntsià, B8oz mù-sàà, B85b mù-sàà, B85d mósày, B85e lí-sày, B85F là-sày, B861 -, B862 là-sày 'announcement', B863-, B864 -, $\mathrm{B} 865$ è-sày, B86U lù-sày, $\mathrm{B} 87$ nsày, $\mathrm{C} 83$-, C84?, C85 rù-sàànk, H42 sâng, L12a Ø-ntsángù.

(10) BLR 496 *átò 'three' BLR 2811 tátò 'three': B72a è-tyk̂عl, B8oz sá:r, B85b tát', B85d tár, B85e tár, B85F tár, B861 âr, B862 sár, $\mathbf{B} 863$ tár, B864 tát, B865 isâr, $\mathbf{B} 86$ sár, $\mathbf{B} 87$ tár, $\mathbf{C} 83$ fćt, C84 hátù, $\mathrm{C}_{5}, \mathrm{H}_{42}$ tát, L12a tátù.

(11) BLR 638 *cóod 'choose': B72a súàl, B8oz ò-swál, Bì-85b -, B85d kò-sósl, B85e ù-sól, B85F kà-só:l, B861 -, B862 ò-fwál, B863 kù-fâl, B864 kj̀-só:l, B865 -, B86 kù-sóól, B87 kà-sól, C83 à-jul, C84?, C85 kù-sór, H42 kù-sól, L12a sól.

(12) BLR 655 *còmb 'borrow, lend': B72a sù̀n, B8oz ò-swìm, B85a swغ̀m 'lend

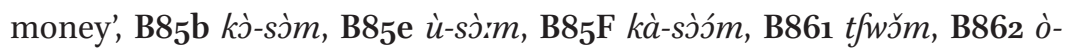

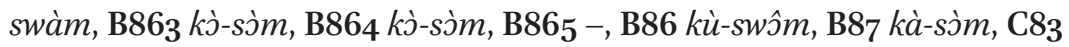

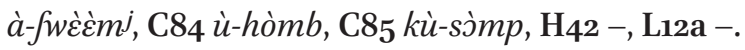

(13) BLR 664 *cónì 'shame': B72a -, B8oz -, B85a nsón 'shameful', B85d?, B85e?, B85F?, B861 è-ntsîn, B862 cán, B863?, B864?, B865n-tsôn, B86Q nsón, B87 -, C83 bu-Jón', C84?, C85?, H42 tsón, L12a Ø-ntsòn 'shame, taboo'.

(14) BLR 893 *ndédé 'whiteman': B72a õ-ndyâl, B8oz mù-ndél, B85b mu-ndel,

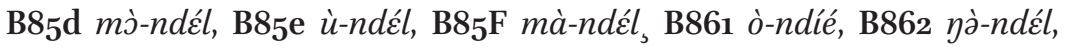
B863 mù-ndél, B864 -, B865 òndyéé, B86 mù-ndél, B87 ù-ndél, C83-, C84-, C85-, $\mathrm{H}_{42}$ mù-ndél, L12a mù-ndél.

(15) BLR 897 *dèdù 'beard, chin': B72a $n d y \dot{\varepsilon} l, \mathbf{B} 80 \mathrm{oz}-, \mathbf{B} 85 \mathrm{~b}$ ndèy, $\mathbf{B} 85 \mathrm{~d}$ ndz̀ts, B85e ndwèy, B85F ndèy, B861 è-lêy, B862 là-lèy, B863 kì-léts, B864 kì-léts, B865-, $\mathbf{B} 86$ ndzèy, $\mathbf{B} 87$ ndwèts, $\mathbf{C} 83$ ndèl, $\mathbf{C} 84$ ndènù, $\mathbf{C} 85$ dùntèn, $\mathbf{H}_{42}$ kìlèf, L12a gí-lèf.

(16) BLR 973 *dímì 'tongue, language, flame': B72a è-lâm, B8oz lè-lím, B85b lèm, B85d lè-lèm, B85e lù-lím, B85F là-lém, B861 è-lâm, B862 là-lám, B863 lù-dím, B864 lù-lém, B865 è-lûm, B86 lù-lém, B87 là-lím, C83 i-ném, C84?, C85 dù-rém, $\mathrm{H}_{42}$-, L12a lú-lìm.

(17) BLR 1046 * dím 'be extinguished, extinguish, get lost': B72a, B8oz-, B85b zím, B85d kò-dzím, B85e ù-dím, B85F kà-dzím, B861 dzím, B862 ò-dám, 
B863 kù-dzím, B864 kò-dzím, B865 ò-zîm, B86 -, B87 kà-dzím, C83 àním, C84?, C85 kù-ním, $\mathrm{H}_{42}$ kù-dzím, L12a gù-dzím.

(18) BLR 1052 * dímb 'forget' or BLR 1054 * dímb 'deceive, (cause to) get lost': B72a $d z \tilde{\varepsilon} \varepsilon \tilde{\varepsilon} n$ 'forget', $\mathbf{B 8 0 z}$-, B85 zím 'forget', $\mathbf{B} 85 \mathbf{d}$ kò-džm 'forget', $\mathbf{B} 85 \mathbf{e}$ ù-dim 'forget', B85F kà-dzim 'forget', B861 dzìm 'deceive', B862 ò-dzím 'forget, deceive, get lost', B863 kù-džmm 'forget', B864-, B865 ò-dzîm 'deceive', B86 kù-dzilim 'forget', $\mathbf{B}_{7}$ kà-dzím 'forget', $\mathrm{C8}_{3}$ à-dim' 'lose', C84 ù-dímb 'deceive', $\mathrm{C}_{5}$ kù-rímp 'forget', $\mathrm{H}_{42}$-, L12a -.

(19) BLR 1080 *dó 'sleep (n.)' BLR 2963 *tòdó 'sleep (n.)': B72a twăl, B80z tòl, B85b t̀̀l', B85d tìl, B85e twàl, B85F tòl, B861 -, B862 twàl, B863 tòl, B864 tòl, B865 tòó, B86 tǒl, B87 tòl, C83-, C84-, C85-, H42 kì-lò, L12a gí-lù.

(20) BLR 1088 *dób 'fish with line': B72a lîb lâb, B8oz?, B85b kù-lób, B85d kj̀lób, B85e ù-lób, B85F kà-lób, B861 lâ̧, B862 ò-lób, B863 kj̀-lób, B864 kj̀-lób, B865-, B86 kù-láb, B87 kà-lĺb, C83?, C84?, C85 kù-róp, H42 kù-lób, L12a -.

(21) BLR 1093 *dóbò 'fish-hook': B72a, B8oz ndj̀b, B85b ndəb, B85d ndj́b, B85e indób, B85F ndób, B861 Ø-ndô $\beta, \mathbf{B} 862$ ndób, B863 ndób, B864 ndób, B865 ndôb, B86U ndób, B87 ndób, C83 i-lóp, C84 -, C85 iróp, $\mathrm{H}_{42}$ ndob, L12a Ø-ndòb.

(22) BLR 1223 *dóngớ '(red) pepper': B72a èndúú, B8oz?, B85b -, B85d è-lúy, B85e ndóy, B85F ndúy, B861 è-lúy, B862 là-lúy, B863-, B864-, B865 ǹ-

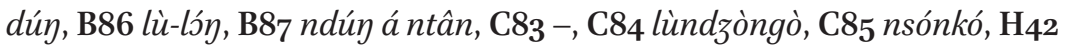
ndûng, L12a ndùng.

(23) BLR 1274 *gàb 'divide, give away, make present': B72a kàb 'share', B8oz ó-kàb 'share, divide in portions', $\mathbf{B} 85 \mathbf{b}$ ku-kab 'share', $\mathbf{B} 85 \mathbf{d}$ kj̀-kàb 'divide', B85e ù-kàb 'share', B85F kà-kàb 'share', B861 kăb, B862 kàb 'share, divide', B863 kù-kàb 'share', B864 kì-kàb 'share', B865 ò-kàbùl 'share, split', B86 kàb 'to share', B87 kà-kàb 'share', C83 à-kàp', C84 ù-kàp, C85 kù-kàb.

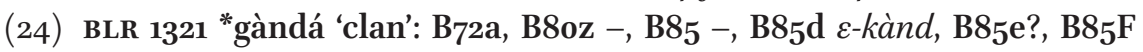
kì-kàn, B861 ò-ykèán 'grandchild', B862 kàn, B863 kì-kànd, B864 kèkànd, B865-, B86, B87 i-kànd, C83-, C84?, C85 i-kànt, H42 ki-kând, L12a gì-gánd.

(25) BLR 1326 *gàndó 'crocodile' BLR 1446 *gòndé 'crocodile': B72a yàán, B8oz ngàn, $\mathbf{B} 85 \mathbf{b}$ ngwen, B85bS ngaan, $\mathbf{B} 85 \mathbf{d}$ ngwên, B85e yáán, $\mathbf{B} 85 \mathrm{~F}$ ngwên, B861 Ø-ykwǒn, B862 nkwààn, B863 ngwên, B864 ngwôn, B865

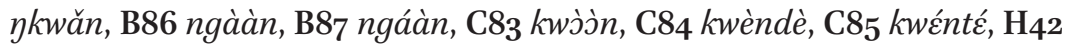
ngând, L12a Ø-ngând.

(26) BLR 1362 "gènd 'walk, travel, go' 3303 *jènd 'walk, travel, go': B72a -, B8oz -, B85b kù-wèn, B85d -, B85e -, B85F kà-wén, B861 kyěn, B862 -, B863 kj̀-kwèn, B864 kj̀-wén, B865 dzyèn 'walking', B86 wèn 'go, leave', B87 wèn, $\mathrm{C}_{3}$ yèż̀n 'go', $\mathrm{C}_{4} 4$ wènd, $\mathrm{C}_{5}$-, $\mathrm{H}_{42}$ kù-kwènè, L12a èndà lùd 'walk'. 
(27) BLR 1368 *gí 'egg' 1378 *gìdí 'egg': B72a -, B8oz ikyżl, B85b Ikye, B85d ć-kyغ̀,

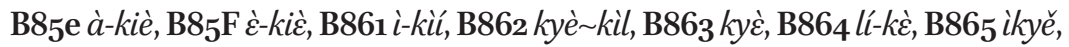
B86 è-kyغ̀, B87 i-kyغ̀, C83 kèl, C84?, C85 i-kèré, H42 kè, L12a ge/még.

(28) BLR 1398 *gidá 'blood': B72a å̀kèl, B8oz mà-kílà, B85a mà-kil, B85d mátsil, B85e á:kil, B85F má-tsil, B861 -, B862 kăl, B863Z má-tsil, B864 mátsil, B865 i-kěl, B86 màkíl, B87 à-tsil, C83 mà-kèl, C84?, C85 mà-kèrà, $\mathrm{H}_{42}$-, L12a -.

(29) BLR 1429 *gòmà 'drum': B72a, B8oz ngòm, B85b ngəm, B85d ngóm, B85e

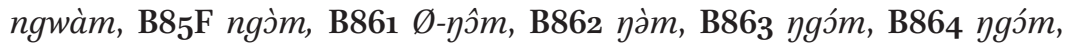

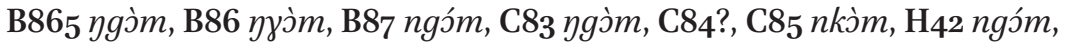
L12a Ø-ngóm.

(30) BLR 1445 *gòndè BLR 1447 * gòndò 'moon, month': B72a -, B8oz ngòn, B85b gwìn 'month', B85d ngòn, B85e ng̀̀n, B85F ngj̀̀n, B861 Ø-ygwôn, B862 ngwàn, B863 ngóón, B864 ngón, B865 ngwèn, B86 ngò̀̀n, B87 jngj̀̀n, C83 ngwì̀n, C84 ngòndù, C85 nkòònt, $\mathrm{H}_{42}$ ngôni, L12a ngónd.

(31) BLR 1509 *gòndà 'forest, garden, luxuriant vegetation': $\mathbf{B}_{72 a}$ ggừún 'field', B80z -, B85a ngwùùn 'field', B85d -, B85e -, B85F -, B861 ò-kûn 'forest for cultivation', B862 -, B863 -, B864 ngûn 'field', B865 -, B86 -, B87 mvûn 'field', C83 ngwò̀n 'field', C84 ngòndò 'field', C85 nkòntó 'field', $\mathrm{H}_{42}$ ngûn 'field', L12a ngúnd 'field'.

(32) BLR 1514 *gòngà 'bell, cuphorn': B72a ygòngà (borrowing), B8oz ngúngà (borrowing), $\mathbf{B} 85 \mathbf{b}$ ngunga (borrowing), $\mathbf{B} 85 \mathbf{d}$ ngùy, $\mathbf{B} 85 \mathrm{e}$ ygùy, $\mathbf{B} 85 \mathrm{~F}$ ngùy, B861 -, B862 -, B863 -, B864 -, B865 y-gùy, B86 ngúy, B87 -, C83 ygwò̀̀, C84 ygòng, $\mathrm{C}_{5} 5$ nkòy, $\mathrm{H}_{42}$ ngûng, L12a Ø-ngúng .

(33) BLR 1532 *gùbó BLR 1480 *gòbú 'hippopotamus': B72a mbvǎb, B8oz

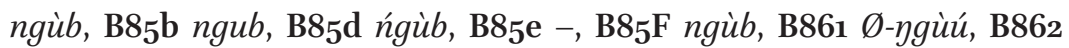
ngàb, B863 ńgùb, B864 ńgùb, B865 ngwùú, B86R ngùú, B87 ńgùb, C83 ygùp, C84?, C85 nkùbú, $\mathbf{H}_{42}$ ńgùf, L12a -.

(34) BLR 1558 *jádà 'fingernail, toenail, claw' BLR 1294 *ádà 'fingernail, toenail, claw': B72a -, B8oz lé-nzàl, B85b zál', B85d li-nzál, B85e lí-gyál, B85F là-dzál, B861 è-kíà, B862 là-dzál, B863 kì-nzál, B864 kè-nzál, B865 è-dzáà, B86 lù-dzál, B87 là-dzál, C83yăàl, C84?, C85yáár, H42 kì-nsár, L12a gíntsal.

(35) BLR 1628 *jòndò 'hammer, anvil, axe, iron': B72a?, B8oz nzwùn, B85b nzùùn, B85d nzù:n, B85e nzûn, B85F nzwòn, B861 Ø-ndzûn, B862 ndzù̀n, B863 nzú:n, B864 nzù:n, B865 -, B86 ndzù:n, B87 ndzún, C83 ntfò̀n, C84?, C85 nsòn, $\mathrm{H}_{42}$ nsùn', L12a nzú:n 'iron, hammer'.

(36) BLR 1674 "kádí 'woman, wife': B72a ồ-kál 'woman', B8oz mù-kér 'woman, wife', $\mathbf{B 8 5} \mathbf{b}$ mu-kyay 'wife', B85d mó-kéts 'wife', $\mathbf{B 8 5} \mathbf{4}$ ù-kyáy 'wife', $\mathbf{B} 85 \mathbf{F}$

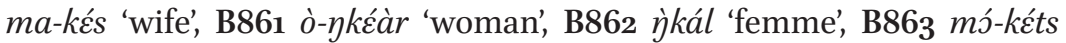
'wife', B864 mó-káts 'wife', B865 mù-kál 'wife, woman', B86 mù-kyáy 'wife', 
B87 ì-kéts 'woman', C83 ygád j 'female', C84 ygátù (?), C85 yár 'wife', $\mathbf{H}_{42}$ mù-kás 'woman', L12a mu-gátf.

(37) BLR 1706 *kàndá 'letter': B72a, B8oz mù-kán, B85 mù-kán, B85d mò-kànd 'announcement', $\mathbf{B 8 5} \mathbf{e}$ káàn, $\mathbf{B} 85 \mathrm{~F}$-, B861 ò-ykèán, B862 -, B863 mú-kànd 'announcement', B864 mó-kànd 'letter, book', B865 òykàán, B86 -, B87 -, C83 nkààn, C84?, C85-, $\mathrm{H}_{42}$-, L12a mù-gánd.

(38) BLR 1793 *kídà 'tail': B72a ò̀-kál, B80z mù-kílà, B85b mú-kíl, B85d mókíl, B85e ùkyúl, B85F mà-kél, B861 ò-yîr, B862 ngàkyél, B863 mùkíl, B864 mòkíl, B865 òkyá, B86 mù-kíl, B87 j̀-kíl, C83 ggél, C84?, C85 nyèr, $\mathbf{H}_{42}$ mú-kír, L12a mú-kil mú-gìl.

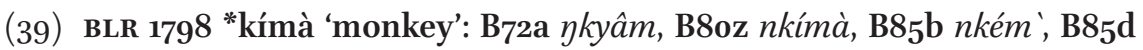
nkim, B85e nkim, B85F nkím, B861 Ø-nkâm, B862 nkyám, B863 nkim, B864 nkím, B865 y-kêm, B86 nkyam, B87 nkím, C83 nkém, C84 kém, C85, $\mathrm{H}_{42}$ khím, L12a kim gim.

(40) BLR 1818 *kíd 'do': B72a -, B8oz ò-kírà, B85b kèt, B85d kì-kír, B85e ù-kyir, B85F kà-kír, B861 kiè, B862 kyàr, B863 kù-kír, B864 kò-kít, B865 ò-kèr, B86Q ò-kèr, B87 kà-kír, C83 à-kèl, C84 kél, C85 kù-kér, H42 kù-kít, L12a-.

(41) BLR 1939 *kòndò 'banana': B72a -, B8oz -, B85b kwàn', B85d ć-kósn, B85e kón, $\mathbf{B} 85 \mathrm{~F}$ ć-kwón ́́-kwáán, B861 -, B862 -, B863 kó:n, B864 kó:n, B865-, B86U i-kì̀n, B87 i-kôn, C83 i-kwj̀̀n, C84 kóndù, C85-, $\mathrm{H}_{42}$ dì-khòn, L12a góndo.

(42) BLR 2041 *kón 'plant, sow': B72a kwên, B8oz ò-kúnà, B85b kón, B85d kòkún, B85e ù-kón, B85F kà-kún, B861 kûn, B862 ò-kwán, B863 kò-kún, B864 kò-kwín, B865 ò-kùn, B86Q kón, B87 kà-kún, C83 wǒon, C84 ù-yún, C85 kùnwín, $\mathrm{H}_{42}$ kù-kún, L12a gún.

(43) BLR 2048 *kóndè 'bean': B72a?, B8oz -, B85b nkwéćn, B85d è-kú:nd, B85e -, B85F -, B861 è-kwôn, B862 kwán, B863 -, B864 -, B865 Đkwôn, B86 nkwén, B87 là-kwân, C83 là-kwóòn, C84?, C85?, H42 -, L12a -.

(44) BLR 2118 *kúmú 'chief, medicine man, rich person': B72a mpfám, B8oz nkùm, B85b nkùm' "cattle owner', B85d mpfúm, B85e mpfûm, B85F mfúm, B861 Ø-ykúm, B862 nkám, B863 mfúm, B864 mfúm, B865 ykúm, B86 mfúm, $\mathbf{B} 87$ mfúm, $\mathbf{C 8}_{3}$ kúm, $\mathbf{C 8} 4$ kúmù, $\mathbf{C}_{5}$ kúmú, $\mathbf{H}_{42}$ pfúm, L12a pfùm.

(45) BLR 2206 *món 'see': B72a mwên, B8oz ò-món, B85b món, B85d kj̀-món, B85e -, B85F -, B861 -, B862 mwán, B863 kù-món, B864 kù-món, B865 j̀-môn, $\mathbf{B} 86$ mwán, B87 kà-món, C83 à-món, C84 món, C85-, H42 kù-món, L12a mòn.

(46) BLR 2212 *mòtí 'one': B72a -, B8oz mòy, B85b mòy, B85d mwès, B85e mwèy, B85F mbès, B861 -, B862 -, B863 mbwès, B864 kè-mòs, B865 j́mòtúk, B86 -, B87 mwès, C83 mmócy, C84 m-ót $f i, \mathbf{C} 85$ mwèts, $\mathbf{H}_{42}$ mòf, L12a móf. 
(47) BLR 2255 *nénè 'big': B72a nến, B8oz nínin, B85b néćn, $\mathrm{B} 85 \mathrm{~d}$ nén, $\mathrm{B} 85 \mathrm{e}$-, B85F -, B861 nínên, B862 nín, B863 nén, B864 nén, B865 -, B86 nén, B87 j̀-nén, $\mathrm{C8}_{3}$ nén, $\mathrm{C} 84$ nênè, $\mathrm{C} 85_{5}$ nén, $\mathrm{H}_{42}$ nén, L12a néné.

(48) BLR 2443 *pémbá 'white clay, kaolin' BLR 2448 pémbé 'white clay, white color': B72a?, B8oz mpéćm, B85b le-pyem, B85d mpém, B85e lipém, B85F?, B861 -, B862 là-pyám, B863 mpé:m, B864 mpéćmb, B865 mpémbé, B86 mpéćm, B87?, C83 yéćm, C84 yèèm, C85 lù-pémpé, $\mathrm{H}_{42}$ lu- $p \hat{\varepsilon} m b$, L12a $p^{h} \varepsilon \dot{m} b$.

(49) BLR 2621 * pòcò ‘skin' BLR 5264 * pòcó 'bark, husk': B72a -, B8oz -, B85b pòy 'skin', B85d è-pùs 'bark', B85e pòy 'bark, skin', B85F è-wùs 'raffia palm tree', B861 è-pûy 'skin', B862 kà-pùj ntà, B863 kì-pùs 'bark', B864 kè-pùs 'bark', B865 mpwè 'bark, peeling, skin', B86 i-pùy 'bark', B87 è-pòs 'bark', C83 yòò 'bark', C84?, C85 pòòs 'skin (animal), peel', H42 kì-pùs 'skin, peel' hùs 'raffia palm tree', L12a gí-pùs 'skin'.

(50) BLR 2731 *tádí 'long': B72a è-tél, B8oz tál, B85b -, B85d -, B85e ètál, B85F -, B861 ò-têy, B862 ò-tál, B863 -, B864 -, B865 ò-tál, B86 tél, B87 -, C83 tádj, C84 tàlè 'big', C85 bù-táré, $\mathrm{H}_{42}$-, L12a - .

(51) BLR 2761 *támbí 'sole of foot, footprint': B72a è-tấá 'foot', B8oz i-táám 'footprint', B85b i-tèàm' 'footprint', B85d l̀-tém 'footprint' , B85e li-tém 'footprint', B85F kì-tá:m 'footprint', B861 -, B862 táám 'foot', B863 lù-tém 'footprint', B864 l’̀-tám 'footprint', B865 -, B86U lù-tyám, B87 là-tám, C83?, C84?, C85 i-támpí, $\mathrm{H}_{42}$ lù-tâm, L12a lù-dámbí.

(52) BLR 3081 *tóng 'put through; thread on string; plait; sew; tie up; build; close (in)': B72a túù 'build', B8oz ò-twù 'braid (hair)', B85b bwó 'build, braid (hair)', B85d kò-túy 'build, braid (hair)', B85e ù-tón 'build, braid

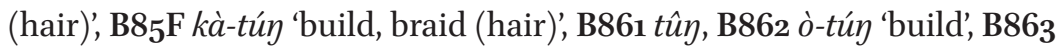
kù-tứ: 'build, braid (hair)', B864 kò-tún 'build, braid (hair)', B865 ò-tûy 'build, braid (hair)', B86 túy 'build, braid (hair)', B87 kà-tún 'build, braid (hair)', C83 à-tóóng 'braid (hair)', C84?, C85 kù-tónk 'build, braid (hair)', $\mathrm{H}_{42}$ kù-tûy 'build', L12a gù-dúng 'build'.

(53) BLR 3101 *túd 'hammer, forge': B72a tswâl/tfâl, B8oz -, B85b sýl, B85d kò-tsúl, B85e ù-tsúl, B85F kà-tsúl, B861 -, B862 ò-túl, B863 kò-tsúl, B864 kò-tsúl, B865 -, B86 kù-tsúl, B87 kà-tsúl, C83 à-túl, C84 ù-tùl, C85 kù-túr, $\mathrm{H}_{42}$ kù-fúl, L12a kù-fúl.

(54) BLR 3252 *játò 'canoe': B72a bvuâl, B8oz vàr, B85 b bwâr, B85d bwâr, B85e bwâr, B85F bwáár, B861 w-âr, B862 bwâr, B863 bwâr, B864-, B865 wăàr, B86U bwàár, $\mathrm{B} 87$ bwâr, $\mathrm{C}_{3}$ bwăàt, $\mathrm{C} 84$ bwàtù, $\mathrm{C}_{5}$ bwăt, $\mathrm{H}_{42}$ bwât, L12a bwâd.

(55) BLR 3472 *jínò 'tooth': B72a dzî̃in, B8oz dzín, B85b zín', B85d غ̀-dzín, B85e gyín, B85F è-dzín, B861 dz-ân, B862 Ø-dzán, B863 Ø-dzín, B864 Ø-dzín, 
$\mathrm{B} 865$ i-dzîn, $\mathrm{B} 86$ i-dzín, B87 i-dzîn, C83 dìn, C84 dï̀ù, C85 dîn, $\mathrm{H} 42$ dîn, L12a lín.

(56) BLR 3579 *jót 'warm oneself': B72a?, B8oz ò-zwár, B85b ò-yj̀r, B85d kj̀wór, B85e ù-yól, B85F kà-wár, B861 - B862 ò-zór, B863 kj̀-wór, B864 kj̀wór, B865 ò-zwár, B86 kù-yór, B87 kà-wór, C83 wǒsk tèy, C84?, C85 kù-wót, $\mathrm{H}_{42}-$, L12a?.

(57) BLR 3598 *jócì 'river': B72a -, B8oz -, B85b mwêy, B85d mwêts, B85e $m w \hat{\varepsilon} y, \mathbf{B} 85 \mathbf{F}$-, B861 -, B862 -, B863 mbwéts, B864 mwêts, B865-, B86U

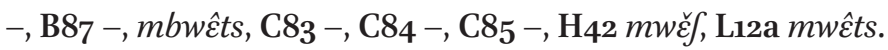

(58) BLR 6024 *bít 'lie down': B72a?, B8oz ò-bér, B85b kò-bír, B85d kò-bír, B85e ù-bír, B85F kà-bír, B861 vâr 'sleep', B862 ò-bár, B863 kù-bír, B864 kò-bít, B865 ò-bér tòó, B86 bít (toวl), B87 kà-bír, C83-, C84?, C85 kù-bés, $\mathrm{H}_{42}$-, L12a -.

(59) BLR 8242 *nàn 'pull, stretch': B72a -, B8oz -, B85bS ò-nàn 'straighten', B85d kj̀-nàn 'pull', B85e ù-nà:n, B85F kà-nàn, B861 -, B862 -, B863 -, B864 kù-nàn, B865 ò-nân 'big, wide, stretched', B86U kù-nàn, B87 kànàn, C83 à-nàn, C84 ù-nân, C85 kù-nàn, $\mathrm{H}_{42}$ kùnàn 'make bigger, stretch', L12a -.

(6o) BLR 8255 *jáná 'palm wine': B72a?, B8oz mánn, B85b -, B85d mán má mbà, B85e mán à bà, B85F mán, B861 v-غ̇án, B862 màn, B863 mán, B864 mán má mbà, $\mathbf{B} 865$ máán, B86 mán, B87 mân, C83 mààn, C84 mà-àn, C85 mán má saampa, $\mathbf{H}_{42}$-, L12a -. 